Author's Final Submitted Version: The orginal article was published in "Current Protein \& Peptide Science" and is available at the Bentham Science website "http://www.eurekaselect.com/122087/article"

\title{
Allergic aspergillosis and the antigens of Aspergillus fumigatus
}

Bharat Singh $^{1}$, Seema Singh ${ }^{1}$, Abdul R. Asif ${ }^{2}$, Michael Oellerich ${ }^{2}$, G. L. Sharma ${ }^{{ }^{*}}$

${ }^{1}$ CSIR-Institute of Genomics and Integrative Biology, University Campus, Mall Road Delhi- 110007, India

${ }^{2}$ Department of Clinical Chemistry, University Medical Center Goettingen, Robert-Koch-Str.40, D-37075 Goettingen, Germany.

E mail: bharatsingh1601@gmail.com, seema.acbrdu@gmail.com, asif@med.uni-goettingen.de michael.oellerich@med.uni-goettingen.de,drglsharma@hotmail.com

\section{*Corresponding author:}

Prof. G. L. Sharma, Ph.D.

Sr. Dy. Director

CSIR- Institute of Genomics and Integrative Biology

University Campus, Mall Road, Delhi-110007, India.

Phone : +91-11-27667439

Fax : +91-11-27667471

E-mail : drglsharma@hotmail.com 


\begin{abstract}
Incidence of fungal infections has increased alarmingly in past few decades. Of the fungal pathogens, the Aspergillus fumigatus has been a major cause of allergic bronchopulmonary aspergillosis (ABPA) which has five main stages - the acute, remission, exacerbation, glucocorticoid dependent and fibrotic stage. The diagnosis of ABPA remains difficult due to its overlapping clinical and radiological features with tuberculosis and cystic fibrosis. From past few decades, the crude fractions of $A$. fumigatus have been used for immunodiagnosis of ABPA. Most of the detection kits based on crude fractions of A. fumigatus are quite sensitive but have low specificity. Till date 21 known and 25 predicted allergens of $A$. fumigatus have been identified. Of these allergens, only five recombinants (rAsp f1-f4 and f6) are commercially used for diagnosis of allergic aspergillosis. Remaining allergens of $A$. fumigatus have been restricted for use in specific diagnosis of ABPA, due to sharing of common antigenic epitopes with other allergens. Complete sequencing of $A$. fumigatus genome identified 9926 genes and the reports on the proteome of A. fumigatus have shown the presence of large number of their corresponding proteins in the pathogen. The analysis of immunoproteomes developed from crude fractions of A. fumigatus by $\operatorname{IgG} / \mathrm{IgE}$ reactivity with ABPA patients and animal sera have identified the panel of new antigens. A brief description on the current status of A. fumigatus antigens is provided in this review. The implementation of advance recombinant expression and peptidomic approaches on the A. fumigatus antigens may help in the selection of appropriate molecules for the development of tools for more specific early diagnosis of ABPA, and desensitization therapies for patients of allergic disorders.
\end{abstract}

Keywords: Allergic aspergillosis, allergens, recombinants, diagnosis, desensitization

\title{
List of abbrevations :
}

Allergic bronchopulmonary aspergillosis (ABPA)

Aspergillus hypersensitivity (AH)

Computed tomography (CT)

Enzyme linked immunosorbent assay (ELISA)

Non invasive aspergillosis (NIA)

Radio allergosorbent test (RAST) 
Skin prick test (SPT)

Thioredoxin (Trx)

Tuberculosis (TB)

Two dimensional gel electrophoresis (2DE)

\section{Introduction}

Among the pathogenic species of Aspergillus, A. fumigatus is the most common cause of aspergillosis which includes a spectrum of diseases. The primary route of infection with Aspergillus has been via inhalation of airborne conidia. The average size of A. fumigatus conidia has been found to be 2.0 to $3.0 \mu \mathrm{m}$. Because of such a small size, the conidia can easily get airborne. Also the conidial production of $A$. fumigatus has been highly prolific and, therefore, the human respiratory tract always remains at risk of acquiring Aspergillus infection [1]. The germination of conidia in the respiratory tract and the extent of mycelial colonization in lungs has been shown to be influenced by the competence of the host immune system [2]. It was reported recently that change in temperature during the growth of A. fumigatus significantly influenced the allergenicity of $A$. fumigatus through differential production of allergenic proteins [3]. In upper airways, the conidia may cause respiratory discomfort due to contact irritation and allergic responses. Aimanianda et al (2009) demonstrated that the hydrophobic nature of rodlet layer prevents immune response against dormant conidia of $A$. fumigatus [4]. Thus it has been suggested that the immunogenic responses may get induced after the release of cellular proteins including virulence factors and allergens from metabolically active germinating conidia. Such initial allergic reactions have been accountable for development of different forms of allergic aspergillosis. Repeated exposure of lungs to conidia, their germination, expansion of hyphal mass and focal growth of $A$. fumigatus in pre-existing lung cavities such as the lesions in patients with pulmonary tuberculosis may lead to the development of noninvasive aspergillomas. The $A$. fumigatus may invade the lung tissues and disseminate to the deeper body parts to cause systemic infection. The increased severity and incidence of allergic and nonallergic aspergillosis need a better understanding of the interplay between host and fungus that contributes to $A$. fumigatus pathogenesis [6]. Also, detailed knowledge of allergenic and antigenic molecules of $A$. fumigatus is required for the selection of molecules for application in specific diagnosis and immunotherapy of aspergillosis. 


\section{Forms of aspergillosis}

\subsection{Allergic}

The A. fumigatus may cause various kinds of allergic conditions in the body of the host. These allergic reactions due to A. fumigatus may lead to the development of four distinct clinically recognizable forms of hypersensitivity respiratory disorders i.e., allergic bronchopulmonary aspergillosis (ABPA), allergic Aspergillus sinusitis, IgE-mediated asthma, and hypersensitivity pneumonitis [5].

In the atopic individuals with diseases of altered lung function such as asthma and cystic fibrosis, A. fumigatus can cause ABPA, a hypersensitive response to fungal products. The ABPA is most common among the other forms of allergic aspergillosis and considered to be an immunologically mediated lung disease, which is very frequently associated with asthma. ABPA has been an idiopathic inflammatory lung disease characterized by hypersensitive allergic response to the colonization of Aspergillus in the airways. It has been the most severe allergic pulmonary complication caused by A. fumigatus. The first case of ABPA was reported from England [7]. The disease existed in USA also and was reported first by Patterson and Golbert in the year of 1968 [8]. Shah (1971) was the first to report three cases of ABPA from India [9]. But it was soon realized that allergic aspergillosis was world wide in distribution. The clinical course of ABPA is known to vary from mild asthma to fatal destruction of lungs with bronchiectasis and fibrosis [10]. Several attempts have been made to determine the prevalence of ABPA but due to lack of uniform diagnostic criteria and standardized tests, it has remained a tough task [11]. The allergic response against Aspergillus was characterized by the presence of an immediate type hypersensitivity reaction to $A$. fumigatus antigens and has been the first step in the development of ABPA [8]. Only a small number of patients with Aspergillus hypersensitivity (AH) have been found to develop the complete clinical picture of ABPA [12]. Chest X-ray and computed tomography (CT) have been found to be useful for establishing diagnosis of ABPA by visualizing the infiltration and bronchiectasis in the lungs of patients. Although, various studies have reported the prevalence of ABPA to be 1.0-2.0\% in asthmatic individuals [5, 9, 11-13], the prevalence of ABPA in severe asthma has been considered to be much higher. In a study of 357 patients with acute severe asthma admitted in the respiratory intensive care unit, the prevalence of ABPA was reported to be $39.0 \%$ [14]. The prevalence of ABPA in patients with cystic fibrosis 
was found to be $2.0-15.0 \%$ [5, 11-13]. In Indian population, the Aspergillus cutaneous type I sensitization was shown to be as high as $28.5-50.0 \%$ [15-17] in asthmatics. In a study by Kumar and Gaur (2000), the prevalence of ABPA was shown to be $16 \%$ in patients of asthma [18]. Maurya et al (2005) carried out a study on 105 patients with bronchial asthma and found 7.5\% prevalence of ABPA [16]. Agarwal et al (2010) reported ABPA prevalence of $27.2 \%$ in a study of 564 asthmatics from North India [14]. High prevalence of ABPA has been reported from various parts of the world and has remained a disease of health importance for clinicians globally especially in Asia.

The overlapping clinical features of ABPA with other respiratory disorders, mainly with tuberculosis (TB) and the difficulties in establishing differential diagnosis, and thereby misdiagnosis quite often, have been the main reasons for wrongly considering ABPA less important [19-21]. It was found that TB has been the most common type of chronic pulmonary infections in developing countries [22]. According to a recent World Health Organization report (2011), the incidence of TB was reported to be $0.185 \%$. In India the incidence of TB has been very high and that contributed over one fifth of the global incidence of TB cases in 2009. Studies from India showed that ABPA was misdiagnosed as TB in $17.0 \%$ to $50.0 \%$ of subjects examined at various hospitals and clinics [14, 21, 23-25]. Free availability of immunosuppressants and their gross misuse in asthmatics increases the risk of Aspergillus infection. Under these conditions the ABPA gets masked and would be diagnosed only at the late stages of disease. There is lack of a universal diagnostic test with high sensitivity and specificity to distinguish between ABPA and TB. The lack of awareness about ABPA among general practitioners, high cost and lack of widespread availability of myco-serological tests, and scarcity of advanced facilities at all clinical centers, have made it difficult to diagnose ABPA in patients of respiratory distress including TB. The diagnosis of ABPA depends on a set of clinical, serological and radiological criteria.

Although typical presentation of ABPA is observed in patients with a history where one finds it difficult to control asthma, the spectrum of presentation has been highly variable and needs to be considered in any patient with moderate to severe asthma and hypersensitivity to $A$. fumigatus. The complaints of ABPA patients have been nonspecific and include dyspnea, wheezing, poor asthma control, cough (commonly productive of thick, brown mucus plugs), 
malaise, low-grade fever and occasionally, hemoptysis. There may be an antecedent history of recurrent asthma exacerbations in conjunction with pneumonia without a culture identified bacterial source. In addition, a history of atopy with rhinitis, drug allergy, and/or allergic conjunctivitis has been common. Very often, the patient remains ill over weeks to months and shows unresponsiveness to standard treatments prescribed on the basis of suggestive diagnosis.

\subsection{Non allergic}

The aspergilloma generally occur in preexisting pulmonary cavities that develop during the course of TB, sarcoidosis, or other bullous lung disorders [26, 27, 28]. About 10.0 to $15.0 \%$ of patients with cavitating lung diseases may develop this syndrome [29]. The aspergilloma consists of an accumulated mass of hyphae embedded in a proteinaceous matrix with sporulating outgrowths on the margin. Hemoptysis was found to be quite frequent in the case of aspergilloma $[30,31]$. The chest radiographs show spheroid mass of hypha generally bordered by a radiolucent crescent [32]. Lesions of aspergillomas in the lung of patients have been superlative demonstrated by CT scans of the chest $[33,34]$. The chronic pulmonary aspergillosis is described as a slightly different condition than aspergilloma due to slow progression of infection by damaging the lung tissues which may result in fibrosis and inflammation in the lungs of host [35]. The occurrence of invasive infection has been usually seen in the setting of an immunocompromised state [36]. The invasive aspergillosis has been recognized as the main fungal infection in cancer patients, however, its true incidence was probably underestimated because of the low sensitivity of diagnostic tests [37]. It also occurs in patients with nonhematogenous underlying conditions such as acquired immunodeficiency syndrome [38] and chronic granulomatous disease [39].

\section{Therapy of aspergillosis}

\subsection{Chemotherapy}

The drugs are available for treatment of Aspergillus induced infections, however, it has been considered that they can only reduce the fungal burden in the host and the cure of infection can rarely be achieved [40]. The drugs currently available for treatment of Aspergillus induced diseases, belong to three major groups (a) Polyenes: Amphotericin, Nystatin, (b) Azoles: Voriconazole, Itraconazole, Posaconazole and (c) Echinocandins: Caspofungin, Micafungin. In 
addition to these molecules, high doses of corticosteroids are nonspecifically prescribed for treatment of ABPA. Although the long-term benefits of corticosteroids are not clear, their many side effects have been the matter of concern. Nebulized corticosteroids with amphotericin B was suggested to improve the outcome of treatment in ABPA [41]. The azoles also have been proposed as an alternative treatment for ABPA. Of this group, the itraconazole was found to be the most active [42]. Both voriconazole and posaconazole are potentially effective alternative treatment options for severe asthma with fungal sensitization and ABPA. Although these drugs may improve asthma control and reduce severity of symptoms, larger prospective studies are required to support the retrospective findings [43]. The glucocorticoids and itraconazole nanosuspension represented an interesting formulation for inhaled administration in CF patients suffering from ABPA [44].

Recently a new approach was explored, where recombinant DNA-derived humanized $\operatorname{IgG}$ (omalizumab) which is an anti-IgE monoclonal antibody, was used to treat 2 patients of cystic fibrosis, in whom frequency of ABPA exacerbations was markedly reduced with treatment, and free titre of IgE was also decreased significantly [46]. Thus it may be considered that omalizumab is useful in treating ABPA in patients with CF and measurement of free IgE may help in monitoring the response to therapy. It was further demonstrated that omalizumab was also useful in patients of severe asthma with fungal sensitization and ABPA [47].

\subsection{Limitations of chemotherapy}

The molecules available for treatment of aspergillosis are not only fewer in number, they have limited efficacy. The amphotericin B is an effective antifungal agent but its therapeutic utility has been hindered due to high toxicity for host cells by channel formation across cell membrane and disruption of postendocytic trafficking [48]. Other anti-Aspergillus drugs also have been found to cause toxic effects as well [49]. Most drugs used for treating aspergillosis have been shown to be immunosuppressive [50]. The development of drug resistance in $A$. fumigatus has become an increasingly serious problem [42, 45]. The drug resistance can be primary (fungal pathogen inherently resistant to antifungal drug) or secondary (development of resistance during treatment). The resistance in Aspergillus to polyenes has been shown to be primary rather than secondary resistance. The primary resistance to polyenes in A. fumigatus has 
been less frequent [51] than in A. terreus. Most A. terreus isolates were found to be resistant to amphotericin B in vitro but were susceptible to itraconazole or voriconazole [52]. In vitro susceptibility of 156 clinical isolates of A. fumigatus to amphotericin B and itraconazole was investigated by microbroth dilution assay. It was observed that $2.0 \mu \mathrm{g} / \mathrm{ml}$ concentration of amphotericin B was lethal to all isolates whereas 4 isolates of $A$. fumigatus were found to be resistant against a high dose $(16.0 \mu \mathrm{g} / \mathrm{ml})$ of itraconazole [53]. There are reports which have demonstrated resistance in Aspergillus species against voriconazole among stem cell transplant recipients [54-56]. The development of resistance in A. fumigatus against azoles and other antifungal agents [45], even if increasing noticeably but still remains a rare event. However, the limited efficacy of current drugs, their toxicity and the issue of development of resisitance in pathogen have emphasized the work on identification of novel antifungal molecules, or alternatively the development of immunotherapy.

\subsection{Immunotherapy}

The efforts have been concentrated at global level for identification of antigenic preparations and/or molecules of $A$. fumigatus which could serve as potential vaccine candidates. In this context, immunization of experimental animals by antigens of Aspergillus has been shown to be effective in desensitization and treating Aspergillus related allergies [57]. It was demonstrated by Fukahori et al (2010) that $A$. fumigatus conidia could regulate the functions of airway dendritic cells in the development of mite allergen-induced allergic airway inflammation [58]. Cenci et al (2000) showed the capability of $A$. fumigatus antigens to elicit Th1 and Th2 type of responses, and it was suggested that crude culture filtrate of A. fumigatus might fulfill the requirement of a candidate vaccine for aspergillosis [59]. A comparative study on culture filtrate and sonicated conidia of $A$. fumigatus as potential vaccine for invasive pulmonary aspergillosis demonstrated that sonicated conidial vaccine was more effective when administered through subcutaneous route [60]. Few individual proteins of $A$. fumigatus have also been tested for their potential as vaccine candidates. These proteins included rAsp f3, rAsp f9/Asp f16, 1,3glucanosyltransferase and aspartic endoprotease which elicited protective immunity against experimental aspergillosis [61-63]. The rAsp f3 provided immunity in cortisone acetateimmunosuppressed mice against experimentally induced pulmonary aspergillosis [61]. A recent study from the same group demonstrated the role of antibodies and $\mathrm{T}$ cells in providing 
immunoprotection. They, however, observed that Asp f3 located in the peroxisomes of A. fumigatus hyphae remained inaccessible to antibodies, unless both cell wall and cell membrane have been permeabilized. The Asp f3 primed CD4+ T cells were not expectedly involved in clearance of fungal pathogen directly, instead they might locally activate immunosuppressed phagocytes to elicit antifungal effect [64]. It was reported very recently that A. fumigatus vaccine based on rAsp $\mathrm{f} 3$ has the potential to prevent aspergillosis in humans [65]. Most studies carried out so far on vaccination, have been limited to the experimental animals only and not even a single protein of those examined for immunoprotection, has reached the level of clinical trail. Therefore, identification of new immuno-therapeutic molecules may serve as potential vaccine candidates.

\section{Diagnosis}

This issue has been haunting clinicians since the recognition of the disease as a distinct entity and even today there has been no single test which can establish the diagnosis of aspergillosis. The diagnosis of ABPA usually relies on a set of criteria and depends on a combination of clinical observations and laboratory investigations.

\subsection{Clinical diagnosis}

A number of major and minor clinical criteria have been proposed to diagnose ABPA [10, 66]. The major criteria include asthma, presence of transient pulmonary infiltrates (fleeting shadows) in chest X-ray, immediate cutaneous reactivity to A. fumigatus, elevated total serum IgE, precipitating antibodies against $A$. fumigatus, peripheral blood eosinophilia, elevated serum $\mathrm{IgE}$ and $\mathrm{IgG}$ specific to A. fumigatus and central/proximal bronchiectasis with tapering of distal bronchi. The minor criteria include expectoration of golden brownish sputum plugs, positive sputum culture for Aspergillus species and late (Arthus-type) skin reactivity to A. fumigatus.

Even with these criteria, there is no consensus regarding the number of conditions to be satisfied to diagnose ABPA. Also patients may not satisfy all these criteria at one point of time and positivity may vary according to the stage of the disease. The basic criteria of Rosenberg et al (1977) subsequently revised by Vlahakis et al (2001) and Greenberger (2002) have been followed wildely for diagnosis of ABPA [10,67,68]. Accordingly the patients of bronchial 
asthma with positive skin prick test against $A$. fumigatus may be diagnosed as ABPA if they meet any four of the following criteria: elevated total $\operatorname{IgE}$, presence of specific $\operatorname{IgE}$ and $\operatorname{IgG}$ against $A$. fumigatus, serum precipitating antibodies against $A$. fumigatus, peripheral blood eosinophilia, transient pulmonary infiltrates on chest X-ray and proximal or central bronchiectasis seen on CT scan.

\subsection{Immunodiagnosis}

The immunodiagnosis of $A$. fumigatus induced diseases has been based on the in vivo (skin prick and intradermal tests) and in vitro tests (radioallergosorbent test, enzyme linked immunosorbent assay and Western blotting). The sensitization of host with allergens of $A$. fumigatus may induce elevated levels of total serum IgE and Aspergillus specific IgE and/or IgG antibodies. The detection of total IgE and Aspergillus specific IgE and IgG antibodies in sera has been considered to be important immunodiagnostic criteria for ABPA [10, 19, 66-69]. The determination of anti-Aspergillus antibodies in sera of suspected subjects was dependent on sensitivity of the test. The skin prick and intradermal tests performed with antigens of Aspergillus have been found to be nonspecific in significant number of individuals [70]. For the skin prick test (SPT) positive allergic patients, the radio allergosorbent test (RAST) and enzyme linked immunosorbent assay (ELISA) were used regularly in laboratories for detection of Aspergillus specific IgE antibodies which show high specificity and sensitivity to detect ABPA. There are few robotic platforms (i.e. ImmunoCap, Phadia, Sweden and Immulite, Siemens, USA) that exist at multispecialty testing centers to perform immunoassays based on crude and specific recombinant antigens of $A$. fumigatus for detection of allergic aspergillosis. The determination of $\mathrm{IgG}$ in the sera of patients against antigens of $A$. fumigatus by manual ELISA was also used for detection of ABPA at the commercial level (De-Meditec, Germany, and DRG International, Inc, USA). However, there has been a lack of antigenic standardization among different laboratories because of the use of local antigen preparations [71]. With no choice of specific antigens for detection of antibodies, only crude antigenic fractions of $A$. fumigatus were commonly used for diagnosis of ABPA. The crude extracts used at different centers for immunodiagnosis of ABPA have not been comparable in their protein composition due to use of different strains [72] and batch-to-batch variations even with same strains, has been quite common [73]. The fungal extracts mainly produced from mycelial cells and/or spores may differ in their protein 
composition [74]. Further, the culture conditions, protein extraction methods and storage procedures have been critical with respect to the quality and quantity of individual allergen in the crude extracts of $A$. fumigatus [75]. These factors may also affect the degradation rate of the extracted proteins in antigenic preparations [76]. There have been instances of frequent variability in antigenic preparations and that may lead to variable sensitivity and specificity of the test [77]. Additionally, the ELISA kits for detection of Aspergillus antigens like, mannan and galactomannan in IA have been considered to be good in specificity but sensitivity was found to be quite variable [78]. Hence in the absence of optimally characterized allergens, the use of locally prepared crude antigenic fractions of $A$. fumigatus for diagnosis of ABPA is continued at different diagnostic centers.

\section{Allergens of A. fumigatus}

\subsection{Known allergens}

The A. fumigatus produces a large number of allergenic molecules which show reactivity with $\operatorname{IgE}$ antibodies derived from patients of ABPA [73, 79, 80]. According to an allergen database, allergome (www.allergome.org), only 23 molecules of A. fumigatus (Asp f1-f13, Asp f15-f18, Asp f22, Asp f23, Asp f27-f29, and Asp f34) have been recorded as allergens. One of these allergens, the Asp f15, has been proposed to be removed from the list due to its sequence similarity with Asp f13. Also the allergen Asp f16 has been shown to have a high degree of homology with Asp f9, thus, making the effective list of 21 allergens of A. fumigatus. Some of these allergens are known for structural, toxic and enzymatic functions and their relationship with virulence also has been reported. However, other allergens do not have virulence properties, except being as immunologically active molecules [81]. These antigenic components increase the risk of allergic aspergillosis because they may redirect the immune response to Th2 type, a response that does not seem to be efficient in eliminating the fungus from the body of host [82].

The description of known allergens of A.fumigatus demonstrated that the Asp f1 has been a major $18 \mathrm{kDa}$ allergen belonging to member of the mitogillin family of cytotoxins [83] and recombinant Asp f1 was used to detect Aspergillus specific antibodies in the sera of patients [84]. The $37 \mathrm{kDa}$ recombinant protein (Asp f2) has been an allergen of A. fumigatus which was evaluated for its immunological properties [85]. The Asp f2 showed IgE binding with ABPA and 
cystic fibrosis patients having ABPA [86]. Hemmann et al (1997) cloned Asp f3 from a cDNA library displayed on phage surface. In an ELISA, serum IgE antibody reactivity to rAsp $\mathrm{f} 3$ was detected in $72.0 \%$ of 89 individuals sensitized to A. fumigatus [87]. There are studies which showed that the rAsp $\mathrm{f} 3$ provided protective immunity in a mice model against experimentally induced aspergillosis [61] which later on was proposed to be a potential vaccine molecules against aspergillosis [64, 65]. The deletion mutation analysis of Asp f4 performed by Ramachandran et al (2004) showed differential reactivity pattern with IgE antibodies derived from sera of ABPA patients [88]. The Asp f5 has been a $43 \mathrm{kDa}$ serine protease of A. fumigatus. Experiments were conducted to study, if Asp f5 contributes to the virulence. Results showed that the gene-disrupted mutants for Asp f5 of A. fumigatus retained virulence and it has been considered to be involved in degradation of lung structural architecture by enzymatic activity [89]. Crameri et al (1996) used serum IgE antibodies from A. fumigatus-sensitized individuals to enrich phage-expressing allergenic proteins [90]. They identified one cDNA encoding for 26.7 kDa manganese superoxide dismutase called Asp f6 sharing 67.2\% homology with human manganese superoxide dismutase which also showed autoreactivity in allergic persons sensitized to Asp $\mathrm{f} 6$ of environmental A. fumigatus. The allergen Asp f8 was identified as acidic ribosomal phosphoprotein type 2 (P2 protein) which also shared $84.0 \%$ sequence homology with human P2 protein. Both recombinant P2 proteins showed strong IgE reactivity and Th1 type skin reactions in A. fumigatus sensitized individuals. These observations suggested that the patients suffering from chronic A. fumigatus allergy be evaluated carefully for in vitro and in vivo humoral and cell-mediated responses to human P2 protein [91]. Another allergen (Asp $\mathrm{f} 9 / \mathrm{Crf}$ ) of A. fumigatus had significant sequence homology with Asp f16 which was identified as cell wall glucanase involved in cell wall assembly. The Asp f9 also showed positive IgE reactivity in allergic patients as demonstrated by ELISA and SPT [79, 92]. The gene encoding for Asp f10 (aspergillopepsin F) was cloned and sequenced by Lee and Kolattukudy [93]. It was reported that Asp f10 can catalyze the hydrolysis of major structural proteins of basement membrane such as elastin, collagen, and laminin in A. fumigatus infected organs of humans. The Asp f11 (cyclophilin) was identified as peptidyl-prolyl cis-trans isomerase and reported as cross-reactive protein across species including humans [94]. Kumar et al (1993) identified a heat shock protein (Hsp 90, Asp f12) of $65 \mathrm{kDa}$ in A. fumigatus [95]. The amino acid sequence of Asp f12 was homologous with Hsp 90 family of heat shock proteins in humans as well as other organisms. The rAsp f12 reacted with IgE and IgG antibodies in the sera of patients with ABPA. The Asp 
f13, which was renamed as Asp $\mathrm{f15}$ (alkaline protease) of A. fumigatus was found to share IgE and IgG epitopes present in allergens of other Aspergillus species [96]. The serine protease of $A$. flavus was found to be cross-reactive with the antibodies prepared against Asp f13/Asp f15 of $A$. fumigatus [97]. Recent studies implied that the complement-degrading activity of Asp f15 was similar with Asp f13 [98]. The gene AFMP1 of A. fumigatus encodes the antigenic cell wall galactomannoprotein (Asp f17) having molecular weight of $31.2 \mathrm{kDa}$. It was also reported that patients with aspergilloma and IA due to A. fumigatus develop a specific antibody response against Asp f17 [99]. Shen et al (2001) cloned and expressed a 34 kDa major allergen (Asp f18) of $A$. fumigatus which was identified as a vacuolar serine proteinase. The results of immunoblot inhibition assay showed IgE cross-reactivity of Asp f18 among major allergens of A. fumigatus, Penicillium notatum and P. oxalicum [100]. Using 2DE immunoblotting, Lai et al (2002) identified a $47 \mathrm{kDa}$ IgE reactive component (Asp f22) in the extracts of A. fumigatus and $P$. citrinum. The IgE cross-reactivity of rAsp $\mathrm{f} 22$ was also detected by immunoblot inhibition experiments with enolases of Alternaria alternata [101]. The Asp f23 of A. fumigatus showed specific binding with $\operatorname{IgG}$ and $\operatorname{IgE}$ antibodies present in sera of ABPA patients and was further characterized as an allergen (60S ribosomal protein L3) of A. fumigatus, by cDNA library screening approach using pooled sera of ABPA patients [102]. The 60S ribosomal protein L3 is found in humans also with $67 \%$ sequence homology to Asp f23. It was, therefore, suggested that there exists a possibility of involvement of A. fumigatus $60 \mathrm{~S}$ ribosomal protein $\mathrm{L} 3$ in autoimmune reactions. A cyclophilin (Asp f27) from A. fumigatus has been cloned, expressed and shown to exhibit cross-reactivity in vitro and in vivo. Glaser et al (2006) identified conserved solvent-exposed residues in the fungal and human cyclophilin that were potentially involved in the IgE-mediated cross-reactivity [103]. The thioredoxins (Trx) of Malasezzia sympodialis and A. fumigatus were identified as novel IgE-binding proteins. The Trx, including the human enzyme, represent cross-reactive domians recognized by binding with serum $\operatorname{IgE}$ from individuals sensitized to $\operatorname{Trx}$ of M. sympodialis. The Mala s13 (a Trx of M. sympodialis) shares $45.0 \%$ sequence identity with human Trx [104]. Glaser et al (2008) cloned human Trx, Mala s13 and 2 thioredoxins (Asp $\mathrm{f} 28$ and Asp f29) of A. fumigatus to produce them as recombinant proteins [105]. All recombinant thioredoxins, including that of human, did bind to IgE from patients with ABPA. Inhibition experiments also showed that the thioredoxins were cross-reactive. The same group of investigators described another allergen (Asp f34) from cDNA library screened for cell wall components. The recombinant Asp f34 showed binding in western blots with IgE antibodies 
derived from A. fumigatus sensitized individuals. It was also found to be involved in the induction of allergen-specific proliferation of PBMCs of patients sensitized to the allergen [106].

\subsection{Predicted allergens}

In addition to the 21 known allergens of $A$. fumigatus, 25 allergens were predicted on the basis of their cross-reactivity and sequence similarities with other potential allergens from several fungal and bacterial sources [107]. These predicted allergens have been identified as alcohol dehydrogenase, $\alpha$-amylase, $\beta$-xylosidase XylA, glutathione S-transferase GliG, molecular chaperone Hsp70, thioredoxin, 60S acidic ribosomal protein P1, aldehyde dehydrogenase AldA, alkaline serine protease Alp1, aryl-alcohol dehydrogenase, $\beta$-Nacetylhexosaminidase NagA, conidial hydrophobin Hyp1/RodA, extracellular lipase, glucan 1,4$\alpha$-glucosidase, histidine acid phosphatase, HLH transcription factor GlcD- $\gamma$, Hsp70 chaperone Hsp88, malate dehydrogenase NAD-dependent, NADH-quinone oxidoreductase Pst2, nuclear transport factor NTF-2, protein disulfide isomerase Pdi1, RNA binding protein MSSP-2, secreted dipeptidyl peptidase DppV, thioredoxin and translation elongation factor 1 subunit Eef1- $\beta$. These predicted allergens are involved in diverse cellular processes such as cellular maintenance and metabolism, and few of them have been characterized as pathogenic determinants. Of the predicted allergens the secreted dipeptidyl peptidase $\mathrm{DppV}$, nuclear transport factor NTF-2, thoredoxins, protein disulfide isomerase Pdil and alkaline serine protease Alp 1 of A. fumigatus have been investigated for their antigenic potential but found to be nonspecifically reactive. Many of the predicted allergens of $A$. fumigatus were found to have significant amino acid sequence homology with potential allergens that were identified from other organisms (http://fermi.utmb.edu/SDAP/sdap_ppm.html). Thus it may be suggested from the available literature on predicted allergens of A. fumigatus that they do not have enough potential to solve the problem of cross reactivity.

\subsection{Use of allergens of $A$. fumigatus in diagnosis}

Of the known and predicted allergens of A. fumigatus 5 namely rAsp f1, rAsp f2, rAsp f3 rAsp f4 and rAsp f6, were shown to have high IgE reactivity [69, 108] and have been used commercially for diagnosis of allergic aspergillosis (Immunocap, Phadia, Uppsala, Sweden). An enzyme immunoassay (the Platelia) developed by Bio-Rad for detection of anti-A. fumigatus IgG 
antibodies, was based on a recombinant $A$. fumigatus antigen. It was evaluated by Guitard et al, (2012) using sera of 551 patients of non invasive aspergillosis (NIA) in 5 different groups that included subjects having definite diagnosis of NIA (group 1; $\mathrm{n}=64$ ), bronchial Aspergillus colonization (group 2; $\mathrm{n}=26$ ), probable aerial Aspergillus contamination (group 3; $\mathrm{n}=44$ ), patients suspected of NIA with negative serological and mycological findings (group $4 ; n=49$ ) and patients not suspected for NIA (group 5; $\mathrm{n}=222$ ). It was found that the methodology was a highly useful screening tool for the diagnosis of NIA [109]. Comparison of conventional diagnostic criteria (detection of anti-A. fumigatus $\mathrm{IgE}, \mathrm{IgG}$, and precipitins) with recently described biomarkers, such as IgE towards recombinant allergens of $A$. fumigatus, revealed that later was an useful tool for diagnosing ABPA in patients of cystic fibrosis [19]. But the application of recombinant allergens has been limited mostly to the IgE detection only. The cross-reactivity of other recombinant allergens of $A$. fumigatus due to sharing of common antigenic epitopes with antigens of other organisms has made it difficult to use them for diagnostic purpose universally [110]. Therefore, to overcome the limitations associated with $A$. fumigatus recombinant molecules or crude antigens based assays, the identification of new and specific allergens has become essential for the development of more specific diagnostic assays to detect allergic aspergillosis in the suspected patients at an early stage of infection.

\section{Complex genome and proteome of $A$. fumigatus}

The genome of $A$. fumigatus has been quite complex and so is the proteome. The release of complete genome sequence of $A$. fumigatus (29.4 megabases), has identified the presence of 9,926 genes in this pathogenic mold [111]. Till date the products of many of these genes have not been identified and are just only predicted. Recent update on genomic data of various Aspergillus species provided resource material for in silico predictions and among them a web based tool, "The Central Aspergillus Resource" enabled to analyze the molecular content of A. fumigatus [112]. Also "The Aspergillus genome database" has included complete comprehensive review of the entire published literature on $A$. fumigatus as well as information on other pathogenic species of Aspergillus. The Aspergillus genome database facilitates comparative genomics by providing a full-featured genomic viewer, as well as matched and standardized sets of genomic information for the sequenced species of Aspergillius [113]. This information could be considered as a background for identification of molecules which are 
unknown yet, but their sequences have been identified in A. fumigatus genome and which might play crucial role in the development of Aspergillus induced allergic and invasive diseases.

The analysis of known and predicted allergens of $A$. fumigatus, suggested that a single molecule may not be sufficient for universal use in diagnosis of ABPA at initial stages of infection [70]. Glaser et al $(2008,2009)$ used cDNA library screening approach in order to improve available diagnostic tools, but selecting the right protein target using cDNA screening proved to be difficult $[105,106]$. Thus the multiple antigens from less explored cytosolic antigenic fraction in combination with secreted molecules may form a panel of potential key determinants for the selection of universally reactive molecules for wider application in early and more specific diagnosis of $A$. fumigatus induced disorders. Recent advances in technologies introduced microarray based allergen chip diagnosis that made it possible to detect IgE against multiple allergens in small amounts of serum [114]. Though the recombinant allergen based chip diagnosis approach appeared to be very promising but still needs evaluation and optimization with regard to selection of allergens for use in the chip assay [115]. In fact cloning and expression of all antigens/allergens of $A$. fumigatus to elucidate their biological functions has not been feasible and the dependence on available less useful few recombinants continues. It is, therefore, important to identify new functional molecules by advanced techniques like proteomic tools, clone them and produce recombinantly for various applications.

It was evident from literature that proteomic characterization of micro organisms became possible after introduction of two dimensional gel electrophoresis (2DE) by O'Farrell (1975) who resolved the complex proteome of E. coli [116]. Since then 2DE has been considered as a powerful tool for separation of proteins from any biological samples. Coupling 2DE with the advanced proteomic analysis techniques like multidisciplinary chromatography and mass spectrometry, served as key to unveil complex pathogenic contents of several microbes. However, the first report on the proteomic based identification of A. fumigatus molecules appeared only a decade back [117]. The possible reasons for such delay in availability of proteomic based information on A. fumigatus, were (i) the difficulties in sample preparation from various fractions i.e. cell wall, secreted, cytosolic and mycelia [118], and (ii) inherent properties responsible for poor separation of fungal proteins by 2DE [119]. Vodisch et al (2009) generated the proteome map of $A$. fumigatus from cytosolic and mitochondrial fractions [120]. Teutschbein 
et al (2010) identified proteins from dormant conidia to provide complete profiling of $A$. fumigatus conidial fraction [121]. Proteomes of A. fumigatus from different early developmental stages [122] and conidial fraction [123] to identify stage specific abundant proteins have been published recently. The above mentioned proteomic studies so far carried out on A. fumigatus indicated that various fractions of this pathogenic mold could be explored for identification of new antigenic proteins. For the purpose of improved and early diagnosis of aspergillosis, a thorough description of immunoproteome of $A$. fumigatus is required because antigens of $A$. fumigatus so far reported are of limited value in detecting the allergic aspergillosis at early stages of infection.

\section{Immunoproteomics of $A$. fumigatus}

In the context of identification of allergens/antigens of $A$. fumigatus few attempts have been made in recent past by using immunoproteomic approach. Gautam et al identified panels of secreted allergens of $A$. fumigatus by $\operatorname{IgE}$ reactivity with sera of ABPA patients [124, 125]. Kumar et al (2011) also identified secreted antigens of $A$. fumigatus by immunoreactivity with sera from ABPA patients and those obtained from immunized animals [126]. An account of potential vaccine candidates from cell wall associated [127] and cytosolic fraction [128] of $A$. fumigatus has been reported.

The studies on immunoproteomes of various fractions i.e. cytosolic and secreted of two geographically diverse strains (Indian and German) of A. fumigatus for identification and characterization of novel immunodominant antigenic molecules that specifically bind to $\operatorname{IgE}$ and IgG antibodies of ABPA patients, were undertaken. The late stage secreted [129], and early stage specific conidial fractions containing cytosolic and cell wall associated proteins [130], were used to identify a panel of new antigenic molecules. A list of 98 antigenic proteins of A. fumigatus identified by Singh et al $[129,130]$ is provided in the Table. These proteins included 9 known (Asp f1-f4, f9, f10, f12, f13/15 and f22) and 6 predicted (dipeptidyl peptidase-V precursor, nuclear transport factor-2, malate dehydrogenase, Hsp70, Hsp88 and alcohol dehydrogenase) allergens of A. fumigatus. Importantly, 19 proteins from the panel identified by Singh et al [129, 130], which are marked with an asterisk [*] in the Table, were used as new molecules by an 
allergen database called allergome (http://www.allergome.org/script/search_step2.php) to update the list of potential allergens of A. fumigatus.

There have been few studies which investigated the effect of antifungal molecules on the proteome of A. fumigatus [131, 132]. Quite interestingly, 34 immunogenic proteins marked with psi $[\psi]$, in the Table were found to show altered expression in the proteome of A. fumigatus due to treatment with an antifungal synthetic coumarin SCD-1 [132], indicating that some of the antigens/allergens of $A$. fumigatus may be important targets for new antifungal therapy. The type of immuoreactivity (IgE, $\operatorname{IgG}$ and $\operatorname{IgG} / \operatorname{IgE}$ both) and the immunodominence are important criteria to be considered for determination of the usability of antigenic molecules of A. fumigatus in diagnosis and therapy of the allergic aspergillosis. Also the production of useful antigens/allergens of $A$. fumigatus recombinantly and their immunological characterization would be essential for possible commercial application.

\section{Strategies for the recombinant expression}

To prepare various antigenic proteins recombinantly, the choice of suitable expression system was always a matter of concern. However, a variety of prokaryotic and eukaryotic expression systems have been evolved to solve expression associated issues. In this section we briefly discuss the expression related problems and their alternate approaches. The prokaryotic systems have remained as first choice for expressing recombinant proteins. Among the prokaryotes, the E. coli has been considered as the most efficient and widely used host for manipulation of DNA and proteins which can express recombinants up to $30 \%$ of its cell mass [133]. The well-known genetics, high transformation efficiency, cultivation simplicity, rapid cell cycle and inexpensiveness, are the main factors that make E. coli to be the preferred host for the recombinant expression of proteins. It was reported that expression of many recombinant allergens of A. fumigatus such as Asp f3 [87], Asp f6 [91], Asp f9/Asp f16 [92], Asp f10 [93], Asp f17 [99] and Asp f23 [102] has been carried out sucessfully in the E. coli. We also produced 1 protein as full length recombinant, selected from a panel of potential allergens of A. fumigatus. This allergen has an mRNA (AFUA_5G03520) of 972 bp which coded for a $37 \mathrm{kDa}$ hypothetical protein (Uniprot ID: Q4WEM3). The recombinant $37 \mathrm{kDa}$ protein was found to be reactive with IgE antibodies of ABPA patients (Unpublished data). 
Although the expression of $37 \mathrm{kDa}$ full length hypothetical protein was achieved, we faced several difficulties while attempting the expression of other selected immunodominant allergens as full length proteins. Therefore, instead of expressing complete gene, reduction of the length of recombinant construct by removing the incompatible regions of DNA and selecting the functional region of target gene has been followed to express partial protein. It was speculated that the expression of partial protein may enhance the solubility of recombinants. It is evident from the literature that many of the genes severely interfere with the survival of E. coli cells during the process of their expression in bacteria and lead to death of host cell or cause significant defects in bacterial growth that dramatically decrease expression capabilities [134]. On the other hand less solubility of the recombinant proteins due to their interaction with inclusion bodies and associated toxicity also remained as major problem which is usually encountered many a times [135]. The occurrence of hydrophobic regions in the antigens is a major feature that caused toxicity to host cells and hindered their expression in E. coli. However, it was also reported that the presence of hydrophobic regions are crucial of the generation of efficient vaccine moieties [136]. The presence of hydrophobic domains in A. fumigatus allergens might have been responsible for inhibiting the full length expression in E. coli. Therefore, the removal of hydrophobic regions from proteins (by gene cloning methods) and retaining a minimal functional domain may allow high level expression of functional proteins in E. coli. To resolve this issue the hydrophobicity index of the allergens of $A$. fumighatus was predicted using a web based tool TopPred v 0.01 (http://mobyle.pasteur.fr/cgi-bin/portal.py?\#forms::toppred) and accordingly selected the less hydrophobic polypeptide of the proteins for recombinant expression. Interestingly, employing this approach, we had been achieved the expression of fructose bisphosphate aldolase class-II (Uniprot ID: Q4WY39) and alcohol dehydrogenase (Uniprot ID: Q4WTV5) in E. coli [130]. It was reported in other pathogens also that the plasmid constructs encoding for truncated parasite antigens (TSOL18 of Taenia solium and EG95 of Echinococcus granulosus) with deleted N- and C-terminal hydrophobic domains significantly improved heterologous expression from insoluble to soluble form of proteins in E. coli [137].

It was suggested that the fusion partner neutralizes the toxic effect of the target protein to some extent and increases the stability of recombinant protein in the expression cells. Some of these fusion partners include glutathione-S-transferase, maltose binding protein, thioredoxin, small ubiquitin modifier, and $\mathrm{N}$-utilization substrate. Of them glutathione-S-transferase and 
maltose-binding protein have an advantage to remain as affinity purification tag also. It was noticed that a single fusion tag will not work for all recombinant proteins, and multiple fusion partners may be needed to be used for successful expression of the soluble recombinants. However, it is important to note that the neutralizing partner of fusion protein may not be enough to eliminate the toxicity of target protein completely. But a strong interaction of fusion partner with target protein, may lead to a suppression of the toxic effect [134]. Recombinant proteins that are toxic to the expression host can be challenging to produce, but this difficulty can usually be overcome by using expression of the recombinant gene in the regulation of an inducible promoter, transcription terminators, control of the plasmid copy number, and/or modification of the coding sequence of the recombinant gene [138]. If the recombinant protein is toxic, it is often useful to determine whether the problem is host cell specific. If so, then the protein can be expressed in a more compatible expression host. Another option could be to use a tightly regulated prokaryotic inducible expression system. The expression of the mammalian apoptosis modulator protein Bax in E. coli is an important example illustrating the rationale design of a neutralizing partner. The Bax protein leads to the lysis of $E$. coli cells at concentrations as low as $0.01 \%$ of total proteins [139]. Attempts to express Bax protein as full length into the periplasm of E.coli failed to diminish its toxic effects, therefore, several strategies have been employed to express it as a fusion protein [140]. We also attempted to express one antigenic protein (sorbitol/xylulose reductase Soul like) in its full length or partial form but recombinant expression was not achieved. Therafter, employing the strategy to express sorbitol/xylulose reductase Soul like, with a fusion partner resulted in recombinant production of protein of 67 $\mathrm{kDa}$ which included a part of $38 \mathrm{kDa}$ of fusion partner which was maintained on its C-terminus (Unpublished data).

Although E. coli has been the first choice over all other expression systems, it has certain limitations. It was reported that the E. coli usually has been incapable of providing the environment suitable for the correct formation of disulfide bonds at the time of expression of the recombinant proteins in the cytoplasm [141]. Formation of disulfide bond in E. coli takes place only in the periplasm in presence of Dsb system [142] and specific periplasmic expression in E. coli reduces yield of protein significantly. It is also seen that E. coli based expression systems were less efficient for post-translational modifications as compared to eukaryotic host. Moreover, the secondary post-translation modifications such as enzyme-mediated N-linked glycosylation, 
O-linked glycosylation, amidation, hydroxylation, myristoylation, palmitation, or sulfation were not supported by E. coli.

To overcome limitations associated with E. coli based systems, the eukaryotic expression systems are the alternate approach. Yeast is the most powerful organism for the manipulation of DNA and expression of recombinant proteins after E. coli. Among yeasts, the Saccharomyces cerevisiae [143] and Pichia pastoris [144] are the routinely used systems because they typically permits higher levels of recombinant protein expression with secondary post translation modifications. The $P$. pastoris has been used to obtain both intracellular and secreted recombinant proteins. Apart from Yeast based expression system, Baculovirus (a lytic, $130 \mathrm{~kb}$ long double-stranded DNA, virus) mediated expression in insect cells (fall armyworm Spodoptera rugiperda, $S f$ 9, Sf 21) offers another useful tool for generating recombinant proteins with secondary modifications [145]. As the last choice, mammalian expression methods have conventionally been taken as the least efficient machinery for expressing recombinant proteins. But due to the excellent property of expressing recombinants with most superior folding and disulfide bond formation in comparison to other expression hosts, the mammalian cells have been used oftenly. Recent advances have significantly improved the expression efficiency of mammalian cell lines. It was reported that the stably transected Chinese hamster ovary cells expressed recombinant antibodies up to a level of a few grams per liter [149, 147].

Employing these strategies on the expression of new antigens of A. fumigatus and developing recombinant based microarray will be helpful for providing new molecules and/or methods with superior applications in diagnostics and desensitization therapies. It was shown that the microarrayed recombinant allergens can be used to determine and monitor the profile of disease-eliciting allergens using single tests that require minute amount of serum from allergic patients [148]. In a cross sectional survey of $\operatorname{IgE}$ reactivity in 23077 patients against a panel of 75 potential allergens was carried out by using microarray based detection system [149]. A chip microarray based on 1205 proteins of Burkholderia pseudomallei, probed with 88 melioidosis patient sera, identified 170 antigens which included 49 specifically reactive antigens and 59 cross-reactive antigens. On the basis of these results, authors devised a test that could classify melioidosis positive and negative individuals with sensitivity and specificity of $95 \%$ and $83 \%$, respectively [150]. 


\section{Antigenic epitopes and peptide library based approaches}

The prediction of antigenic epitopes and exploration of peptide library screening approaches have several advantages. It was found that full length sequence of a protein in terms of immune-recognition may contain several non antigenic and hypo-antigenic regions. For the characterization of total antigenic structure of a protein, identification of $\operatorname{IgE}$ and/or $\operatorname{IgG}$ binding epitopes is a determinant factor. The dissimilarity in the linear and conformational epitopes in the same protein, is a confounding factor for type of reactivity. A link between paratope, epitope and mimotopte influences the definition of a specific interaction between antigen and antibody [151]. The mimotope can bind antibody without any relation in the sequence of protein antigen used to induce antibody [152]. It was suggested that the $\operatorname{IgE}$ binding epitopes are more cross reactive than the IgG binding epitopes. This might be due to the presence of structural mimics (mimotopes) of the hyper-allergenic epitopes of the antigenic proteins. The mimotopes have the capabilities to mimic not only peptides, even they can recognize carbohydrate, lipid or haptens including biotin and they can not be easily mapped on the 3 dimensional structures of antigens [151]. The phenomenon of cross reactivity which occurs mostly with the allergens of $A$. fumigatus may be due to presence of mimotopes of other proteins which hamper the specific reactivity of the target allergens. Thus, avoiding the regions of antigens which contain mimotopes has to be an important criterion while designing the peptide libraries from the newly identified allergens. The peptide microarrays have become increasingly usable in recent years for diagnostic applications [153].

In a recent report, the use of a bioinformatic approach for epitope prediction, their synthesis and evaluation on peptide microarray was described. It was shown that such array was a powerful method for the selection of Toxoplasma gondii epitopes for serological diagnosis of toxoplasmosis with diagnostic specificity of $84 \%$ [154]. The replacement of lengthy polypeptides of the antigenic proteins with short, synthetic peptides is virtually a straightforward approach to capture antigen-specific antibodies from serum samples, however, both the immuno-biological display of peptides on support and their performance in microarray based immunoassay are often unsuccessful on application [155]. Antibody epitope mapping using synthetic peptide array has been shown to be useful for mapping of full sequence of antigens for the identification of hyperantigenic epitopes [156]. Several strategies were suggested to generate hypoallergic variants of 
allergens to use them as vaccine candidates [157]. The peptide microarray data was also used for the analysis of target specificity of protein [158]. Recently Chen et al, (2012) identified immunodominant epitopes of Pen c13, a major allergen of $P$. citricum by generation of peptides by enzymatic cleavage of full length protein [159]. Further the mutant (G270A) generation of Pen c13, containing IgE binding epitopes revealed their application in diagnosis/prognosis of mold allergy, whereas another hypoallergenic mutant (K274A) of the Pen c13, may provide a framework for the design and development of a safe and efficient therapeutic strategy for treating human allergic diseases.

\section{Conclusion}

It could be inferred from the above description that the diagnosis of allergic aspergillosis at the early stages of infection, and its effective treatment is extremly difficult. Therefore, ABPA remains encumber on the human health globally. The limitations in terms of cross-reactivity of known and predicted allergens of $A$. fumigatus diminished their diagnostic relevance. Also the molecules characterized as pathogenic/virulence factors of the A. fumigatus are not very much promising in development of strategies for detection of ABPA. Furthermore, the difficulties have been encountered while expressing several biologically functional and immunodominant antigenic/allergenic molecules of $A$. fumigatus recombinantly. The immunoproteomic studies on crude secreted and cytosolic fractions of $A$. fumigatus identified a panel of new immunogenic molecules. In silico assesment of these molecules provided predictive information on the topology, antigenicity, linear and/or conformational architecture of the epitopes in their amino acid sequences. Characterization as full length recomibinant and generation of peptide libraries on the basis of newly identified antigens of $A$. fumigatus may have potential applications in the diagnostic and therapeutics. However, the selection of the specific allergen and thereafter, identification of peptides from single or multiple proteins is the utmost difficult task. Hence a thorough screening of the peptides derived from novel antigens, and preparation of their different compositions are essentially required to minimize the occurrence of mimotopes. The effective methods for immobilization of the selected $\operatorname{IgE}$ and $\operatorname{IgG}$ reactive peptides on the microchips to construct the tools for the development of peptide based chip array of customized molecules will be useful in specific and early diagnosis of allergic forms of aspergillosis. Also the thoroughly 
characterized antigenic/allergenic molecules of $A$. fumigatus and the suitable peptides from them may have immunotherapeutic potential against $A$. fumigatus induced disorders.

\section{References}

1. Latge, J.P. The pathobiology of Aspergillus fumigatus. Trends Microbiol, 2001, 9, 382-89.

2. Dixon, D.M.; Polak, A.; Walsh, TJ. Fungus dose-dependent primary pulmonary aspergillosis in immunosuppressed mice. Infect. Immun., 1989, 57, 1452-1456.

3. Low, S.Y.; Dannemiller, K.; Yao, M.; Yamamoto, N.; Peccia, J. The allergenicity of Aspergillus fumigatus conidia is influenced by growth temperature. Fungal Biol. 2011, $115,625-32$.

4. Aimanianda, V.; Bayry, J.; Bozza, S.; Kniemeyer, O.; Perruccio, K.; Elluru, S.R.; Clavaud, C.; Paris. S; Brakhage, A.A.; Kaveri, S.V.; Romani. L; Latge, J.P. Surface hydrophobin prevents immune recognition of airborne fungal spores. Nature Lett., 2009, 460, 1117-121.

5. McNeil, MM.; Nash, SL.; Hajjeh, R.A.; Phelan, M.A.; Conn, L.A.; Plikaytis, B.D.; Warnock, D.W. Trends in mortality due to invasive mycotic diseases in the United States, 1980-1997. Clin. Infect. Dis., 2001, 33, 641-47.

6. Shah, A.; Panjabi, C. Allergic bronchopulmonary aspergillosis: a review of a disease with a worldwide distribution. J. Asthma, 2002, 39, 273-89.

7. Hinson, K.F.W.; Moon, A.J.; Plummer, N.S. Bronchopulmonary aspergillosis. Thorax, 1952, 7, 317-33.

8. Patterson, R.; Golbert, F. Hypersensitivity disease of the lung. Univ. Mich. Med. Cent. J., 1968, 34, 8-11.

9. Shah, J.R. Allergic bronchopulmonary aspergillosis. J. Assoc. Phys. India, 1971, 19, 83541.

10. Rosenberg, M.; Patterson, R.; Mintzer, R.; Cooper, B.J.; Roberts, M.; Harris, K.E. Clinical and immunological criteria for the diagnosis of allergic bronchopulmonary aspergillosis. Ann. Intern. Med., 1977, 86, 405-14.

11. Bedi, R.S.; Bedi, G.K. Allergic bronchopulmonary aspergillosis : Indian scenario. Lung India, 2007, 24, 156-161. 
12. Agarwal, R.; Chakrabarti, A. Epidemiology of allergic bronchopulmonary aspergillosis. In: Pasqualotto A, ed. Aspergillosis: from diagnosis to prevention. New York, NY: Springer, 2010, 4, 671-88.

13. Schwerk, N.; Rochwalsky, U.; Brinkmann, F.; Hansen, G. Don't forget other causes of wheeze. ABPA in a boy with asthma. A case report and review of the literature. Acta Paediatr., 2011, 10, 307-310.

14. Agarwal, R.; Nath, A.; Aggarwal, A.N.; Gupta, D.; Chakrabarti, A. Aspergillus hypersensitivity and allergic bronchopulmonary aspergillosis in patients with acute severe asthma in a respiratory intensive care unit in North India. Mycoses, 2010, 53, 138 43.

15. Chakrabarti, A.; Sethi, S.; Raman, D.S.; Behera, D. Eight-year study of allergic bronchopulmonary aspergillosis in an Indian teaching hospital. Mycoses, 2002, 45, 295 299.

16. Maurya, V.; Gagnani, H.C.; Sarma, P.V.; Madan, T.; Shah, A. Sensitization to Aspergillus antigens and occurrence of bronchopulmonary aspergillosis in patients with asthma. Chest, 2005, 127, 1252-259.

17. Agarwal, R.; Gupta, D.; Aggarwal, A.N.; Behera, D.; Jindal, S.K. Allergic bronchopulmonary aspergillosis: Lessons from 126 patients attending a chest clinic in north India. Chest, 2006, 130, 442-48.

18. Kumar, R.; Gaur, S.N. Prevalence of Allergic bronchopulmonary aspergillosis in patients with bronchial asthma. Asian P. J. Allergy Immunol., 2000, 18, 181-85.

19. Delhaes, L.; Frealle, E.; Pinel, C. Serum markers for allergic bronchopulmonary aspergillosis in cystic fibrosis: State of the art and further challenges. Med. Mycol., 2010, 48, S77-87.

20. Min, K.H.; Park, S.J.; Kim, S.R.; Lee, M.H.; Chung, C.R.; Han, H.J.; Choi, K.H.; Chung, M.J.; Lee, Y.C.; Jin, G.Y.; Kim, M.H. Coexistence of allergic bronchopulmonary aspergillosis and active pulmonary tuberculosis., Am. J. Respir. Crit. Care Med., 2011, 183,137-9.

21. Tripathi, S.K.; Srivastava, R.; Tg, R.; Anand, S. Allergic bronchopulmonary aspergillosis: still a mirage or ignorance. BMJ Case Rep. 2012, pii: bcr0120125584.

22. Falagas, M.E.; Voidonikola, P.T.; Angelousi, A.G. Tuberculosis in patients with systemic rheumatic or pulmonary diseases treated with glucocorticosteroids and the preventive role of isoniazid: a review of the available evidence. Int. J. Antimicrob. Agents, 2007, 30, 47786.

23. Agarwal, R.; Singh, N.; Aggarwal, A.N. An unusual association between Mycobacterium tuberculosis and Aspergillus fumigatus. Monaldi Arch. Chest Dis., 2008, 69, 32-34. 
24. Bedi, R.S. Allergic bronchopulmonary aspergillosis: Review of 20 cases. Indian J. Chest Dis. Allied Sci., 1994, 36, 181-86.

25. Behera, D.; Guleria, R.; Jindal, S.K.; Chakrabarti, A.; Panigrahi, D. Allergic bronchopulmonary aspergillosis: A retrospective study of 35 cases. Indian J. Chest Dis. Allied Sci., 1994, 36, 173-79.

26. Israel, H.L.; Lenchner, G.S.; Atkinson, G.W. Sarcoidosis and aspergilloma. Chest, 1982, $82,430-32$.

27. Wollschlager, C.; Kan, F. Aspergilloma complicating sarcoidosis. A prospective study in 100 patients. Chest, 1984, 86, 585-88.

28. Kirsten, D.; U, Rieger.; M, Amthor.; H, Magnussen. Invasive aspergillosis in cavitary lung sarcoidosis. Pneumologie, 1992, 46, 239-242.

29. Addrizzo-Harris, D.J.; Harkin, T.J.; McGuinness, G.; Naidich, D.P.; Rom, W. Pulmonary aspergilloma and AIDS a comparison of HIV-infected and HIV-negative individuals. Chest, 1997, 111, 612-18.

30. Dixon, D.D.; Walsh, T.J. Human pathogenesis, In (eds), Bennett JW, Klich MA, Aspergillus, biology and industrial application. Butterworth-Heinemann, Boston, Mass, 1992, 249-67.

31. Faulkner, S.L.; Vernon, R.; Brown, P.P.; Fisher, R.D.; Bender HW. Hemoptysis and pulmonary aspergilloma: operative versus nonoperative treatment. Ann. Thorac. Surg, 1978, 25, 389-392.

32. Broderick, L.S.; Conces, D.J.; Tarver, R.D.; Bergmann, C.A.; Bisesi, M.A. Pulmonary aspergillosis: a spectrum of disease. Crit. Rev. Diagn. Imaging, 1996, 37: 491-31.

33. Offner, F.; Cordonnier, C.; Ljungman, P.; Prentice, H.G.; Engelhard, D.; De Bacquer, D.; Meunier, F.; De Pauw, B.; Impact of previous aspergillosis on the outcome of bone marrow transplantation. Clin. Infect. Dis., 1998, 26, 1098-103.

34. Richard, C.; Romon, I.; Baro, J.; Insunza, A.; Loyola, I.; Zurbano, F.; Tapia, M.; Iriondo, A.; Conde, E.; Zubizarreta, A. Invasive pulmonary aspergillosis prior to BMT in acute leukemia patients does not predict a poor outcome. Bone Marrow Transplant, 1993, 12, $237-41$.

35. Denning, D.W.; Pleuvry, A.; Cole, D.C.; Global burden of chronic pulmonary aspergillosis as a sequel to pulmonary tuberculosis. Bull. World Health Organ., 2011, 89, 864-72.

36. Karim, M.; Alam, M.; Shah, A.A.; Ahmed, R.; Sheikh, H. Chronic invasive aspergillosis in apparently immunocompetent hosts. Clin. Infect. Dis., 1997, 24, 723-33. 
37. Kaiser, L.T.; Huguenin, P.D.; Lew, B.; Pittet, D. Invasive aspergillosis. Clinical features of 35 proven cases at a single institution. Medicine, 1998, 77, 188-94.

38. Nash, G.; Irvine, R.; Kerschmann, R.L.; Herndier, B. Pulmonary aspergillosis in acquired immune deficiency syndrome: autopsy study of an emerging pulmonary complication of human immunodeficiency virus infections. Hum. Pathol, 1997, 28, 1268-275.

39. Denning, D.W. Invasive aspergillosis. Clin. Infect. Dis., 1998, 26, 781-803.

40. Latge, J.P. Aspergillus fumigatus and aspergillosis. Clin. Microbiol. Rev., 1999, 12, 31050 .

41. Laoudi Y.; Paolini J.B.; Grimfed A.; Just J. Nebulised corticosteroid and amphotericin B: an alternative treatment for ABPA? Eur. Respir. J., 2008, 31, 908-9.

42. Elphick, H.E.; Southern, K.W.; Antifungal therapies for allergic bronchopulmonary aspergillosis in people with cystic fibrosis. Cochrane Database Syst. Rev. 2012, 13, CD002204.

43. Chishimba, L.; Niven, R.M.; Cooley, J.; Denning, D.W. Voriconazole and posaconazole improve asthma severity in allergic bronchopulmonary aspergillosis and severe asthma with fungal sensitization. J. Asthma. 2012, 49,423-33.

44. Rundfeldt, C.; Steckel, H.; Scherliess, H.; Wyska, E.; Wlaź, P. Inhalable highly concentrated itraconazole nanosuspension for the treatment of bronchopulmonary aspergillosis. Eur. J. Pharm. Biopharm. 2012. pii: S09396411(12)00316-5.

45. Camps, S.M.; van der Linden, J.W.; Li, Y.; Kuijper, E.J.; van Dissel, J.T.; Verweij, P.E.; Melchers, W.J. Rapid induction of multiple resistance mechanisms in Aspergillus fumigatus during azole therapy: a case study and review of the literature. Antimicrob. Agents Chemother., 2012, 56, 10-16.

46. Elmallah, M.K.; Hendeles, L.; Hamilton, R.G.; Capen, C.; Schuler, P.M. Management of patients with cystic fibrosis and allergic bronchopulmonary aspergillosis using antiimmunoglobulin E therapy (Omalizumab). J. Pediatr. Pharmacol. Ther. 2012, 17, 88-92.

47. Hogan, C.; Denning, D.W. Allergic bronchopulmonary aspergillosis and related allergic syndromes. Semin. Respir. Crit. Care Med., 2011, 32, 682-92.

48. Kagan S, Ickowicz D, Shmuel M, Altschuler Y, Sionov E, Pitusi M, Weiss A, Farber $\mathrm{S}$, Domb AJ, Polacheck I. Toxicity mechanisms of amphotericin B and its neutralization by conjugation with arabinogalactan. Antimicrob. Agents. Chemother. 2012, 56, 5603-11

49. Howard, S.J.; Arendrup, M.C. Acquired antifungal drug resistance in Aspergillus fumigatus: epidemiology and detection. Med. Mycol., 2011, 49, S90-5. 
50. Steinbach, W.J.; Stevens, D.A.; Denning, D.W.; Moss, R.B. Advances against aspergillosis. Clin. Infect. Dis., 2003, 37, S155-156.

51. Masia Canuto, M.; Gutierrez Rodero, F. Antifungal drug resistance to azoles and polyenes. Lancet Infect. Dis., 2002, 2, 550-563.

52. Sutton, D.A.; Sanche, S.E.; Revankar, S.G.; Fothergill, A.Q.; Rinaldi, M.G. In vitro amphotericin B resistance in clinical isolates of Aspergillus terreus, a head-to-head comparison of voriconazole. Clin. Infect. Dis., 2004, 39, 743-46.

53. Dannaoui, E.; Persat, F.; Monier, M.R.; Borel, E.; Piens, M.A.; Picot, S. In vitro susceptibility of Aspergillus supp. isolates amphotericin B and itraconazole. $J$. Antimicrob. Chemother., 1999, 44, 553-55.

54. Imhof, A.; Balajee, S.A.; Fredricks, D.N.; Englund, J.A.; Marr, K.A. Breakthrough fungal infections in stem cell transplant recipients receiving voriconazole. Clin. Infect. Dis., 2004, 39, 743-46.

55. Marty, F.M.; Cosimi, L.A.; Baden, L.R. Breakthrough zygomycosis after voriconazole treatment in recipients of hematopoietic stem cell transplants. N. Engl. J. Med., 2004, 350, 950-52.

56. Siwek, G.T.; Dodgson, K.J.; De Magahaes-Silverman, M.; Bartelt, L.A.; Kilborn, S.B.; Hoth, P.L.; Diekema, D.J.; Pfaller, M.A. Invasive zygomycosis in hematopoietic stem cell transplant recipients receives voriconazole prophylaxis. Clin. Infect. Dis., 2004, 39, 584-87.

57. Stevens, D.A.; Vaccinate against aspergillosis! A call to arms of the immune system. Clin. Infect. Dis, 2004, 38, 1131-316.

58. Fukahori, S.; Matsuse, H.; Tsuchida, T.; Kawano, T.; Tomari, S.; Fukushima, C.; Kohno, $\mathrm{S}$. Aspergillus fumigatus regulates mite allergen-pulsed dendritic cells in the development of asthma. Clin. Exp. Allergy, 2010, 40, 1507-1515

59. Cenci, E.; Mencacci, A.; Bacci, A.; Bistoni, F.; Kurup, V.P.; Romani, L. T Cell Vaccination in mice with invasive pulmonary aspergillosis, J. Immunol., 2000, 165, 38188 .

60. Ito, J.I.; Lyons, J.M. Vaccination of corticosteroid immunosuppressed mice against invasive pulmonary Aspergillosis. J. Infect. Dis., 2002, 186, 869-71.

61. Ito, J.I.; Lyons, J.M.; Hong, T.B.; Tamae, D. Vaccinations with recombinant variants of Aspergillus fumigatus allergen Asp f 3 protect mice against invasive aspergillosis. Infect. Immun., 2006, 74, 5075-084.

62. Bozza, S.; Gaziano, R.; Lipford, G. B.; Montagnoli, C.; Bacci, A.; Di Francesco, P.; Kurup, V. P.; Wagner, H.; Romani, L. Vaccination of mice against invasive aspergillosis 
with recombinant Aspergillus proteins and $\mathrm{CpG}$ oligodeoxynucleotides as adjuvants. Microbes Infect, 2002, 4(13), 1281-1290.

63. Bozza, S.; Clavaud, C.; Giovannini, G.; Fontaine, T.; Beauvais, A.; Sarfati, J.; D'Angelo, C.; Perruccio, K.; Bonifazi, P.; Zagarella, S.; Moretti, S.; Bistoni, F.; Latge, J. P.; Romani, L. Immune sensing of Aspergillus fumigatus proteins, glycolipids, and polysaccharides and the impact on Th immunity and vaccination. J Immunol, 2009, 183(4), 2407-2414.

64. Diaz-Arevalo, D.; Bagramyan, K.; Hong, T.B.; Ito, J.I. T cells mediate the protective effect of the recombinant Asp f3-based anti-aspergillosis vaccine. Infect. Immun., 2011, 79, 2257-266.

65. Diaz-Arevalo, D.; Ito, J.I.; Kalkum, M.; Protective effector cells of the recombinant Asp f3 Anti-Aspergillosis vaccine. Front. Microbiol., 2012, 3, 299.

66. Wang, J.L.F.; Patterson, R.; Rosenberg, M.; Roberts, M.; Cooper, B.J. Serum IgE and IgG antibody activity against Aspergillus fumigatus as a diagnostic aid in allergic bronchopulmonary aspergillosis. Am. Rev. Respir. Dis., 1978, 117, 917-27.

67. Vlahakis, N.E.; Aksamit, T.R. Diagnosis and treatment of allergic bronchopulmonary aspergillosis. Mayo Clin. Proc., 2001, 76, 930-38.

68. Greenberger, P.A. Allergic bronchopulmonary aspergillosis. J. Allergy Clin. Immunol., 2002, 110, 685-92

69. Kurup, V.P.; Knutsen, A.P.; Moss, R.B.; Bansal, N.K. Specific antibodies to recombinant allergens of Aspergillus fumigatus in cystic fibrosis patients with ABPA. Clin. Mol. Aller., 2006, 4, 11 .

70. Kurup, V.P. Aspergillus antigens: which are important? Med. Mycol., 2005, 43, S189196.

71. de Oliveira, E.; Giavina-Bianchi, P.; Fonseca, L.A.; Franca, A.T.; Kalil, J. Allergic bronchopulmonary aspergillosis' diagnosis remains a challenge. Respir. Med. 2007, 101, 2352-357.

72. Steringer, I.; Aukrust, L.; Einarsson, R. Variability of antigenicity/allergenicity in different strains of Alternaria alternata. Int. Arch. Allergy Appl. Immunol., 1987, 84, 19097.

73. Vailes, L.D.; Perzanowski, M.S.; Wheatley, L.M.; Platts-Mills, T.A.; Chapman, M.D. $\operatorname{IgE}$ and $\operatorname{IgG}$ antibody responses to recombinant Alt a 1 as a marker of sensitization to Alternaria in asthma and atopic dermatitis. Clin. Exp. Allergy, 2001, 31, 1891-895.

74. Paris, S.; Fitting, C.; Ramirez, E.; Latge J.P.; David, B. Comparison of different extraction methods of Alternaria allergens. J. Allergy Clin. Immunol., 1990, 85, 941-48. 
75. Horner, W.E.; Helbling, A.; Salvaggio, J.E.; Lehrer, S.B. Fungal allergens. Clin. Microbiol. Rev., 1995, 8, 161-79.

76. Ferreira, F.; Wallner, M.; Thalhamer, J. Customized antigens for desensitizing allergic patients. Adv. Immunol., 2004, 84, 79-129.

77. Sharma, G.L.; Bhatnagar, P.K.; Chattopadhya, D.; Sarma, P.U. Analysis of HIV seropositive thalassemic children for antibodies specific to Aspergillus fumigatus by luminiscent immunoassay. J. Clin. Lab Anal., 1997, 11, 343-45.

78. Barnes, R.A. Early diagnosis of fungal infection in immunocompromised patients. $J$. Antimicrob. Chemoth., 2008, 61, i3-i6.

79. Crameri, R. Recombinant Aspergillus fumigatus allergens: from the nucleotide sequences to clinical applications. Int. Arch. Allergy Immunol., 1998, 115, 99-114.

80. Crameri, R.A. Jr.; Gamcsik, M.P.; Brooking, R.M.; Najvar, L.K.; Kirkpatrick, W,R,; Patterson, T.F.; Balibar, C.J.; Graybill, J.R.; Perfect, J.R.; Abraham, S.N.; Steinbach, W.J. Disruption of a nonribosomal peptide synthetase in Aspergillus fumigatus eliminates gliotoxin production. Eukaryot. Cell, 2006, 5, 972-80.

81. Abad, A.; Ferna'ndez-Molina, J.V.; Bikandi, J.; Ramı're, A.; Margareto, J.; Sendino, J.; Hernando, F.L.; Pontón, J.; Garaizar, J.; Rementeria, A. What makes Aspergillus fumigatus a successful pathogen? Genes and molecules involved in invasive aspergillosis. Rev. Iberoam. Micol., 2010, 27, 155-82.

82. Hebart, H.; Bollinger, C.; Fisch, P.; Sarfati, J.; Meisner. C.; Baur, M.; Loeffler, J.; Monod, M.; Latgé, J.P.; Einsele, H. Analysis of T-cell responses to Aspergillus fumigatus antigens in healthy individuals and patients with hematologic malignancies. Blood, 2002, $100,4521-28$.

83. Arruda, L.K.; Mann, B.J.; Chapman, M.D. Selective expression of a major allergen and cytotoxin, Asp f I, in Aspergillus fumigatus. Implications for the immunopathogenesis of Aspergillus-related diseases, J. Immunol., 1992, 149, 3354-359.

84. Moser, M.; Crameri, R.; Menz, G.; Schneider, T.; Dudler, T.; Virchow, C.; Gmachl, M.; Blaser, K.; Suter, M. Cloning and expression of recombinant Aspergillus fumigatus allergen I/a (rAsp f I/a) with IgE binding and type I skin test activity. J. Immunol., 1992, $149,454-60$

85. Banerjee, B.; Kurup, V.P.; Phadnis, S.; Greenberger, P.A.; Fink, J.N. Molecular cloning and expression of a recombinant Aspergillus fumigatus protein Asp f II with significant immunoglobulin E reactivity in allergic bronchopulmonary aspergillosis. J. Lab Clin. Med. 1996, 127, 253-62.

86. Banerjee, B.; Greenberger, P.A.; Fink, J.N.; Kurup, V.P. Immunological characterization of Asp $\mathrm{f} 2$, a major allergen from Aspergillus fumigatus associated with allergic bronchopulmonary aspergillosis. Infect. Immun., 1998, 66, 5175-182. 
87. Hemmann, S.; Blaser, K.; Crameri, R. Allergens of Aspergillus fumigatus and Candida boidinii share IgE-binding epitopes. Am. J. Respir. Crit. Care Med., 1997, 156, 1956-962.

88. Ramachandran, H.; Banerjee, B.; Greenberger, P.A.; Kelly, K.J.; Fink, J.N. Kurup, V.P. Role of C-terminal cysteine residues of Aspergillus fumigatus allergen Asp f 4 in immunoglobulin E binding. Clin. Diagn. Lab Immunol., 2004, 11, 261-65.

89. Markaryan, A.; Morozova, I.; Yu, H.; Kolattukudy, P.E. Purification and characterization of an elastinolytic metalloprotease from Aspergillus fumigatus and immunoelectron microscopic evidence of secretion of this enzyme by the fungus invading the murine lung. Infect. Immun., 1994, 62, 2149-257.

90. Crameri, R.; Blaser, K. Cloning Aspergillus fumigatus allergens by the pJuFo filamentous phage display system. Int. Arch. Allergy Immunol., 1996, 110, 41-45.

91. Mayer, C.; Appenzeller, U.; Seelbach, H.; Achatz, G.; Oberkofler, H.; Breitenbach, M.; Blaser, K.; Crameri, R. Humoral and cell-mediated autoimmune reactions to human acidic ribosomal P2 protein in individuals sensitized to Aspergillus fumigatus P2 protein. J. Exp. Med., 1999, 189, 1507-512.

92. Banerjee, B.; Kurup, V.P.; Greenberger, P.A.; Johnson, B.D.; Fink, J.N. Cloning and expression of Aspergillus fumigatus allergen Asp f 16 mediating both humoral and cellmediated immunity in allergic bronchopulmonary aspergillosis (ABPA). Clin. Exp. Allergy, 2001, (5), 761-70.

93. Lee, J.D.; Kolattukudy, P.E. Molecular cloning of the cDNA and gene for an elastinolytic aspartic proteinase from Aspergillus fumigatus and evidence of its secretion by the fungus during invasion of the host lung. Infect. Immun., 1995, 63, 3796-803.

94. Fluckiger, S.; Scapozza, L.; Mayer, C.; Blaser, K.; Folkers, G.; Crameri, R. Immunological and structural analysis of IgE-mediated cross-reactivity between manganese superoxide dismutases. Int. Arch. Allergy Immunol., 2002, 128, 292-303.

95. Kumar, A.; Reddy, L.V.; Sochanik, A.; Kurup, V.P. Isolation and characterization of a recombinant heat shock protein of Aspergillus fumigatus. J. Allergy Clin. Immunol., 1993, 91, 1024-030.

96. Shen, H.D.; Tam, M.F.; Chou, H.; Han, S.H. The importance of serine proteinases as aeroallergens associated with asthma. Int. Arch. Allergy Immunol., 1999, 119, 259-64.

97. Kolattukudy, P.E.; Lee, J.D.; Rogers, L.M.; Zimmerman, P.; Ceselski, S.; Fox, B.; Stein, B.; Copelan, E.A. Evidence for possible involvement of an elastolytic serine protease in aspergillosis. Infect. Immun., 1993, 61, 2357-368.

98. Rambach, G.; Dum, D.; Mohsenipour, I.; Hagleitner, M.; Würzner, R.; Lass-Flörl, C.; Speth, C. Secretion of a fungal protease represents a complement evasion mechanism in cerebral aspergillosis. Mol. Immunol., 2010, 47, 1438-449. 
99. Yuen, K.Y.; Chan, C.M.; Chan, K.M.; Woo, P.C.Y.; Che, X.Y.; Leung, A.S.P.; Cao, L. Characterization of AFMP1: a novel target for serodiagnosis of aspergillosis. J. Clin. Microbiol., 2001, 39, 3830-307.

100. Shen, H.D.; Lin, W.L.; Tam; M.F.; Chou, H.; Wang, C.W.; Tsai, J.J.; Wang, S.R.; Han, S.H. Identification of vacuolar serine proteinase as a major allergen of Aspergillus fumigatus by immunoblotting and N-terminal amino acid sequence analysis. Clin. Exp. Allergy, 2001, 31, 295-302.

101. Lai, H.Y.L.; Tam, M.F.; Tang, R.B.; Chou, H.; Chang, C.Y.; Tsai, J.J.; Shen, H.S. cDNA cloning and immunological characterization of a newly identified enolase allergen from Penicillium citrinum and Aspergillus fumigatus. Int. Arch. Allergy Immunol., 2002, 127, $181-90$

102. Saxena, S.; Madan, T.; Muralidhar, K.; Sarma, P.U. cDNA cloning, expression and characterization of an allergenic L3 ribosomal protein of Aspergillus fumigatus. Clin. Exp. Immunol., 2003, 134, 86-91.

103. Glaser, A.G.; Limacher, A.; Flückiger, S.; Scheynius, A.; Scapozza, L.; Crameri, R. Analysis of the cross-reactivity and of the 1.5 A crystal structure of the Malassezia sympodialis Mala s 6 allergen, a member of the cyclophilin pan-allergen family. Biochem. J., 2006, 396, 41-9.

104. Limacher, A.; Glaser, A.G.; Meier, C.; Schmid-Grendelmeier, P.; Zeller, S,; Scapozza, L.; Crameri, R. Cross-reactivity and 1.4-A crystal structure of Malassezia sympodialis thioredoxin (Mala s 13), a member of a new pan-allergen family. J. Immunol., 2007, 178, $389-96$.

105. Glaser, A.G.; Menz, G.; Kirsch, A.I.; Zeller. S.; Crameri, R.; Rhyner, C. Auto- and Cross-reactivity to thioredoxin allergens in allergic bronchopulmonary aspergillosis. Allergy, 2008, 63, 1617-623.

106. Glaser, A.G.; Kirsch, A.I.; Zeller, S.; Menz, G.; Rhyner, C.; Crameri, R. Molecular and immunological characterization of Asp $\mathrm{f} 34$, a novel major cell wall allergen of Aspergillus fumigatus. Allergy, 2009, 64, 1144-151.

107. Fedorova, N.D.; Khaldi, N.; Joardar, V.S.; Maiti, R.; Amedeo, P.; Anderson, M.J.; Crabtree, J.; Silva, J.C.; Badger, J.H.; Albarraq, A.; Angiuoli, S.; Bussey, H.; Bowyer, P.; Cotty, P.J.; Dyer, P.S.; Egan, A.; Galens, K.; Fraser-Liggett, C.M.; Haas. B.J.; Inman, J.M.; Kent, R.; Lemieux, S.; Malavazi, I.; Orvis, J.; Roemer, T.; Ronning, C.M.; Sunadram, J.P.; Sutton, G.; Turner, G.; Venter, J.C.; White, O.R.; Whitty, B.R.; Youngman, P.; Wolfe, K.H.; Goldman, G.H.; Wortman, J.R.; Jiang, B.; Denning, D.W.; Nierman, W.C.; Genomic island in the pathogenic filamentous fungus Aspergillus fumigatus. Plos Gen., 2008, 4, 1-13.

108. Knutsen, A.P.; Hutcheson, P.S.; Slavin, R.G.; Kurup, V.P. IgE antibody to Aspergillus fumigatus recombinant allergens in cystic fibrosis patients with allergic bronchopulmonary aspergillosis. Allergy, 2004, 59, 198-203. 
109. Guitard, J.; Sendid, B.; Thorez, S.; Gits, M.; Hennequin, C. Evaluation of a recombinant antigen-based enzyme immunoassay for the diagnosis of noninvasive aspergillosis. $J$. Clin. Microbiol. 2012, 50,762-65.

110. Crameri, R.; Zeller, S.; Glaser, A.G.; Vilhelmsson, M.; Rhyner. Cross-reactivity among fungal allergens: a clinically relevant phenomenon? Mycoses, 2009, 52, 99-106.

111. Nierman, W.C.; Pain, A.; Anderson, M.J.; Wortman, J.R.; Kim, H.S.; Arroyo, J,; Berriman, M.; Abe, K.; Archer, D.B.; Bermejo, C.; Bennett, J.; Bowyer, P.; Chen, D.; Collins, M.; Coulsen, R.; Davies, R.; Dyer, P.S.; Farman, M.; Fedorova, N.; Fedorova, N.; Feldblyum, T.V.; Fischer, R.; Fosker, N.; Fraser, A.; Garcia, J.L.; Garcia, M.J.; Goble, A.; Goldman, G.H.; Gomi, K.; Griffith-Jones, S.; Gwilliam, R/; Haas, B.; Haas, H.; Harris, D.; Horiuchi, H.; Huang, J.; Humphray, S.; Jimenez, J.; Keller, N.; Khouri, H.; Kitamoto, K.; Kobayashi, T.; Konzack, S.; Kulkarni, R.; Kumagai, T.; Lafon, A.; Latge, J.P.; Li, W.; Lord, A.; Lu, C.; Majoros, W.H.; May, G.S.; Miller, B.L.; Mohamoud, Y.; Molina, M.; Monod, M.; Mouyna, I.; Mulligan, S.; Murphy, L.; O'Neil, S.; Paulsen, I.; Penalva, M.A.; Pertea, M.; Price, C.; Pritchard, B.L.; Quail, M.A.; Rabbinowitsch, E.; Rawlins. N.; Rajandream, M.A.; Reichard, U.; Renauld, H.; Robson, G.D.; Rodriguez, d.C.; Rodriguez-Pena, J.M.; Ronning, C.M.; Rutter, S.; Salzberg, S.L.; Sanchez, M.; Sanchez-Ferrero, J.C.; Saunders, D.; Seeger, K.; Squares, R.; Squares, S.; Takeuchi, M.; Tekaia, F.; Turner, G.; Vazquez de Aldana, C.R.; Weidman, J.; White, O.; Woodward, J.; Yu, J.H.; Fraser, C.; Galagan, J.E.; Asai, K.; Machida, M.; Hall, N.; Barrell, B.; Denning, D.W.; Genomic sequence of the pathogenic and allergenic filamentous fungus Aspergillus fumigatus. Nature, 2005, 438, 1151-156.

112. Gilsenan, M.J.; Cooley, J.; Bowyer, P. CADRE: the Central Aspergillus Data Repository 2012. Nucleic Acids Res., 2011, 32, D401-405.

113. Arnaud, M.B.; Cerqueira, G.C.; Inglis, D.O.; Skrzypek, M.S. The Aspergillus Genome Database (AspGD): recent developments in comprehensive multispecies curation, comparative genomics and community resources. Nucleic Acids Res., 2011, 40, D653-59.

114. Ott, H.; Baron1, J.M.; Heise, R.; Ocklenburg, C.; Stanzel, S.; Merk, H.F.; Niggemann, B.; Beyer, K. Clinical usefulness of microarray-based IgE detection in children with suspected food allergy. Allergy, 2008, 63, 1521-528.

115. Schmid-Grendelmeier, P. Recombinant allergens. For routine use or still only science? Hautarzt., 2010, 61, 946-53.

116. O'Farrell, P.H. High resolution two-dimensional electrophoresis of proteins. J. Biol. Chem., 1975, 250, 4007-021.

117. Bruneau, J.M.; Magnin, T.; Tagat, E.; Legrand, R.; Bernard, M.; Diaquin, M.; Fudali, C.; Latge, J.P. Proteome analysis of Aspergillus fumigatus identifies glycosylphosphatidylinositol-anchored proteins associated to the cell wall biosynthesis. Electrophoresis, 2001, 22, 2812-823. 
118. Kniemeyer, O.; Lessing, F.; Scheibner, O.; Hertweck, C.; Brakhage, A.A. Optimisation of a 2-D gel electrophoresis protocol for the human-pathogenic fungus Aspergillus fumigatus. Curr. Genet., 2006, 49, 178-89.

119. Kniemeyer, O.; Brakhage, A.A. Proteomics and its application to the human-pathogenic fungi Aspergillus fumigatus and Candida albicans. Human and Animal Relationships, 2nd Edition The Mycota, 2008, VI, 155-186.

120. Vodisch, M.; Albrecht, D.; Leßing, F.; Schmidt, A.D. Two-dimensional proteome reference maps for the human pathogenic filamentous fungus Aspergillus fumigatus. Proteomics, 2009, 9, 1407-415.

121. Teutschbein, J.; Albrecht, D.; Potsch, M.; Guthke, R.; Aimanianda, V.; Clavaud, C.; Latgé, J.P.; Brakhage, A.A.; Kniemeyer, O. Proteome profiling and functional classification of intracellular proteins from conidia of the Aspergillus fumigatus. $J$. Proteome Res., 2010, 9, 3724-742.

122. Cagas, S.E.; Jain, M.R.; Li, H.; Perlin, D.S. The proteomic signature of Aspergillus fumigatus during early development. Mol. Cell Proteomics, 2011 11, M111.010108.

123. Suh, M.J.; Fedorova, N.D.; Cagas, S.E.; Hastings, S.; Fleischmann, R.D.; Peterson, S.N.; Perlin, D.S.; Nierman, W.C.; Pieper, R.; Momany, M. Development stage-specific proteomic profiling uncovers small, lineage specific proteins most abundant in the Aspergillus fumigatus conidial proteome. Proteome Sci., 2012, 10, 30.

124. Gautam, P.; Madan, T.; Gade, W.N.; Sarma, P.U. Immunoproteomic analysis of secretory proteins of Aspergillus fumigatus with specific IgE immunoreactivity. Indian J. Clin. Biochem. 2006, 21(2), 12-19.

125. Gautam, P.; Sundaram, C.S.; Madan, T.S.; Gade, W.N.; Shah, A.; Sirdeshmukh, R.; Sarma, P.U. Identification of novel allergens of Aspergillus fumigatus using immunoproteomics approach. Clin. Exp. Allergy, 2007, 37, 1239-249.

126. Kumar, A.; Ahmed, R.; Singh, P.K.; Shukla, P.K. Identification of virulence factors and diagnostic markers using immunosecretome of Aspergillus fumigatus. J. Prot., 2011, 742, 1104-112.

127. Asif, AR.; Oellerich, M.; Armstrong, V.W.; Riemenschneider, B.; Monod, M.; Reichard, U. Proteome of conidial surface associated proteins of Aspergillus fumigatus reflecting potential vaccine candidates and allergens. J. Prot. Res., 2006, 5, 954-62.

128. Asif, A.R.; Oellerich, M.; Amstrong, V.W.; Gross, U.; Reichard, U. Analysis of the cellular Aspergillus fumigatus proteome that reacts with sera from rabbits developing an acquired immunity after experimental aspergillosis. Electrophoresis, 2010, 31, 1947-958.

129. Singh, B.; Oellerich, M.; Kumar, R.; Kumar, M.; Bhadoria, D.P.; Reichard, U.; Gupta, V.K.; Sharma, G.L.; Asif, A.R. Immuno-reactive molecules identified from the secreted proteome of Aspergillus fumigatus. J. Prot. Res., 2010, 9, 5517-29. 
130. Singh, B..; Sharma, G.L.; Oellerich, M.; Kumar, R.; Singh, S.; Bhadoria, D.P.; Katyal, A.; Reichard, U.; Asif, A.R.; Novel cytosolic allergens of Aspergillus fumigatus identified from germinating conidia. J. Prot. Res., 2010, 9, 5530-41.

131. Gautam, P.; Shankar, J.; Madan, T.; Sirdeshmukh, R.; Sundaram, C.S.; Gade, W.N.; Basir, S.F.; Sarma, P.U. Proteomic and transcriptomic analysis of Aspergillus fumigatus on exposure to Amphotericin B. Antimicrob. Agents. Chemo., 2008, 52,4220-227.

132. Singh, S.; Gupta, S.; Singh, B.; Sharma, S.K.; Gupta, V.K.; Sharma, G.L. Proteomic characterization of Aspergillus fumigatus treated with an antifungal coumarin for identification of novel target molecules of key pathways. J. Prot. Res., 2012, 11, 32593268 .

133. Jana, S.; Deb, J.K. Strategies for efficient production of heterogenous proteins in Escherichia coli. Appl. Microbiol. Biotechnol., 2005, 67, 289-298.

134. Saïda, F.; Uzan, M.; Odaert, B.; Bontems, F. Expression of Highly Toxic Genes in E. coli: Special Strategies and Genetic Tools. Curr. Prot. Pep. Sci., 2006, 7, 47-56.

135. Sørensen, H.P.; Mortensen, K.K. Soluble expression of recombinant proteins in the cytoplasm of Escherichia coli. Microb. Cell Fact., 4, 2005, (doi:10.1186/1475-2859-4-1).

136. Delbecq, S.; Hadj-Kaddour, K.; Randazzo, S.; Kleuskens, J.; Schetters, T.; Gorenflot, A.; Précigout, E. Hydrophobic moeties in recombinant proteins are crucial to generate efficient saponin-based vaccine against Apicomplexan Babesia divergens. Vaccine, 2006; 24, 613-21.

137. Gauci, C.; Jenkins, D.; Lightowlers, M.W. Strategies for optimal expression of vaccine antigen from Taeniid Cestode parasites in Escherichia coli. Mol. Biotechnol., 2011, 48, 277-289.

138. Khow, O.; Suntrarachun, S. Strategies for production of active eukaryotic proteins in bacterial expression system. Asian Pacific J. Trop. Biomed., 2012, 159-162.

139. Asoh, S.; Nishimaki, K.; Nanbu-Wakao, R.; Ohta, S. A trace amount of the human proapoptotic factor Bax induces bacterial death accompanied by damage of DNA. J. Biol. Chem., 1998, 273, 11384-91.

140. Donnelly, M.I.; Stevens, P.W.; Stols, L.; Su, S.X.; Tollaksen, S.; Giometti, C.; Joachimiak, A. Expression of a highly toxic protein, Bax, in Escherichia coli by attachment of a leader peptide derived from the GroES cochaperone. Protein Expr. Purif., 2001, 22, 422-29.

141. Bardwell, J. C. Building bridges: Disulphide bond formation in the cell. Mol. Microbiol., 1994, 14, 199-205. 
142. Andersen, C.L.; Matthey-Dupraz, A.; Missiakas, D.; and Raina, S. A new Escherichia coli gene, dsbG, encodes a periplasmic protein involved in disulphide bond formation, required for recycling DsbA/DsbB and DsbC redox proteins. Mol. Microbiol, 1997, 26, 121-132.

143. Strausberg, R. L.; Strausberg, S.L. Overview of protein expression in Saccharomyces cerevisiae. Curr. Protoc. Protein Sci., 2001, Chapter 5, Unit 5.6.

144. Cregg, J.M.; Barringer, K.J.; Hessler, A.Y.; Madden, K.R. Pichia pastoris as a host system for transformation. Mol. Cell. Biol, 1985, 5, 3376-3385.

145. Kost, T.A.; Condreay, J.P.; Jarvis, D.L. Baculovirus as versatile vectors for protein expression in insect and mammalian cells. Nat. Biotechnol, 2005, 23, 567-575.

146. Figueroa, B.; Ailor, E.; Osborne, D.; Hardwick, J.M.; Reff, M.; Betenbaugh, M.J. Enhanced cell culture performance using inducible anti-apoptotic genes E1B-19 K and Aven in the production of a monoclonal antibody with Chinese Hamster Ovary cells. Biotechnol. Bioeng, 2007, 97, 877-892.

147. Wurm, F.M. Production of recombinant protein therapeutics in cultivated mammalian cells. Nature Biotechnol., 2004, 22, 1393-1398.

148. Harwanegg, C.; Hiller, R. Protein microarrays in diagnosing IgE-mediated diseases: spotting allergy at the molecular level. Expert Rev. Mol. Diagn., 2004, 4, 539-48.

149. Scala, E.; Alessandri, C.; Bernardi, M.L.; Ferrara, R.; Palazzo, P.; Pomponi, D.; Quaratino, D.; Rasi, C.; Zaffiro, A.; Zennaro. D.; Mari, A. Cross-sectional survey on immunoglobulin E reactivity in 23,077 subjects using an allergenic moleculebasedmicroarray detection system. Clin. Exp. Allergy, 2010, 40, 911-21.

150. Felgner, P.L.; Kayala, M.A.; Vigil, A.; Burk, C.; Nakajima-Sasaki, R.; Pablo, J.; Molina, D.M.; Hirst, S.; Chew, J.S.; Wang, D.; Tan, G.; Duffield, M.; Yang. R.; Neel, J.; Chantratita, N.; Bancroft, G.; Lertmemongkolchai, G.; Davies, D.H.; Baldi, P.; Peacock, S.; Titball, R.W. A Burkholderia pseudomallei protein microarray reveals serodiagnostic and crossreactive antigens. Proc. Natl. Acad. Sci. U S A., 2009, 106, 13499-504.

151. Aalberse, R.C.; Crameri, R. IgE-binding epitopes: a reappraisal. Allergy, 2011, 66, 126174.

152. Meloen, R.H.; Puijk, W.C.; Slootstra, J.W. Mimotopes: realization of an unlikely concept. J. Mol. Recognit., 2000, 13, 352-359.

153. Uttamchandani, M.; Yao, S.Q.; Peptide microarrays: next generation biochips for detection, diagnostics and high-throughput screening. Curr. Pharm. Des., 2008, 14, 2428 38 . 
154. Maksimov, P.; Zerweck, J.; Maksimov, A.; Hotop, A.; Gross, U.; Pleyer, U.; Spekker, K.; Däubener, W.; Werdermann, S.; Niederstrasser, O.; Petri, E.; Mertens, M.; Ulrich, R.G.; Conraths, F.J.; Schares, G. Peptide microarray analysis of in silico-predicted epitopes for serological diagnosis of Toxoplasma gondii infection in humans. Clin. Vaccine Immunol. 2012, 19, 865-74.

155. Andresen, H.; Bier, F.F. Peptide microarrays for serum antibody diagnostics Methods. Mol. Biol., 2009, 509, 123-34.

156. Reineke, U.; Kramer, A.; Schneider-Mergener, J. Antigen sequence- and library-based mapping of linear and discontinuous protein-protein-interaction sites by spot synthesis. Curr. Top Microbiol. Immunol., 1999, 243, 23-36.

157. Vrtala, S.; Focke-Tejkl, M.; Swoboda, I.; Kraft, D.; Valenta, R. Strategies for converting allergens into hypoallergenic vaccine candidates. Methods, 2004, 32, 313-20.

158. Rychlewski, L.; Fischer, D.; Elofsson, A. LiveBench-6: large-scale automated evaluation of protein structure prediction servers. Proteins, 2003, 53, 542-7.

159. Chen, J.C.; Chiu, L.L.; Lee, K.L.; Huang, W.N.; Chuang, J.G.; Liao, H.K.; Chow, L.P. Identification of critical amino acids in an immunodominant IgE epitope of Pen c 13, a major allergen from Penicillium citrinum. PLoS One, 2012, 7, e34627.

160. Moser, M.; Menz, G.; Blaser, K.; Crameri, R. Recombinant expression and antigenic properties of a 32-kilodalton extracellular alkaline protease, representing a possible virulence factor from Aspergillus fumigatus. Infect. Immun. 1994, 62,936-42.

161. Chow, L.P.; Liu, S.L.; Yu, C.J.; Liao, H.K.; Tsai, J.J.; Tang, T.K. Identification and expression of an allergen Asp f 13 from Aspergillus fumigatus and epitope mapping using human IgE antibodies and rabbit polyclonal antibodies. Biochem. J. 2000, 346, 2, 423-31.

162. Beauvais, A.; Monod, M.; Debeaupuis, J.P.; Diaquin, M.; Kobayashi, H.; Latge, J.P. Biochemical and antigenic aharacterization of a new Dipeptidyl-peptidase isolated from Aspergillus fumigatus. J. Biol. Chem. 1997, 272, 6238-244.

163. Cheng, C.Y.; Chang, C.H.; Wu, Y.J.; Li, Y.K. Exploration of glycosyl hydrolase family 75, a chitosanase from Aspergillus fumigatus. J. Biol. Chem., 2006, 281, 3137-144.

164. Mouyna, I.; Hartland, R.P.; Fontaine, T.; Diaquin, M.; Simenel, C.; Delepierre, M.; Henrissat, B.; Latgé, J.P. A 1,3-beta-glucanosyltransferase isolated from the cell wall of Aspergillus fumigatus is a homologue of the yeast Bgl2p. Microbiology, 1998, 144, 317180 .

165. Weichel, M.; Schmid-Grendelmeier, P.; Fluckiger, S.; Breitenbach, M.; Blaser, K.; Crameri, R. Nuclear transport factor 2 represents a novel cross-reactive fungal allergen. Allergy, 2003, 58, 198-206. 
166. Tronchin, G.; Esnault, K.; Sanchez, M.; Larcher, G.; Marot-Leblond, A.; Bouchara, J.P. Purification and partial characterization of a 32-Kilodalton sialic acid-specific lectin from Aspergillus fumigatus. Infect. Immun., 2002, 70, 6891-895.

167. Reichard, U.; Eiffert, H.; Rüchel, R. Purification and characterization of an extracellular aspartic proteinase from Aspergillus fumigatus. J. Med. Vet. Mycol., 1995, 33, 279.

168. Hartland, R.P.; Fontaine, T.; Debeaupuis, J.P.; Simenel, C.; Delepierre, M.; Latgé, J.P. A novel beta-(1-3)-glucanosyltransferase from the cell wall of Aspergillus fumigatus. $J$. Biol. Chem., 1996, 271, 26843-9.

169. Mouyna, I.; Fontaine, T.; Vai, M.; Monod, M.; Fonzi, W.A.; Diaquin, M.; Popolo, L.; Hartland, R.P.; Latgé, J.P. Glycosylphosphatidylinositol-anchored glucanosyltransferases play an active role in the biosynthesis of the fungal cell wall, $J$. Biol. Chem., 2000, 275, 14882-889.

170. Fontaine, T.; Magnin, T.; Melhert, A.; Lamont, D.; Latge, J.P.; Ferguson, M.A. Structures of the glycosylphosphatidylinositol membrane anchors from Aspergillus fumigatus membrane proteins. Glycobiology, 2003, 13, 169-177.

171. Jaques, A.K.; Fukamizo, T.; Hall, D.; Barton, R.C.; Escott, G.M.; Parkinson, T.; Hitchcock, C.A.; Adams, D.J. Disruption of the gene encoding the ChiB1 chitinase of Aspergillus fumigatus and characterization of a recombinant gene product. Microbiology, 2003, 149, 2931-939.

172. Alcazar-Fuoli, L.; Clavaud, C.; Lamarre, C.; Aimanianda, V.; Seidl-Seiboth, V.; Mellado, E.; Latgé, J.P. Functional analysis of the fungal/plant class chitinase family in Aspergillus fumigatus. Fungal Genet. Biol. 2011, 48,418-29.

173. Calera, J.A.; Paris, S.; Monod, M.; Hamilton, A.J.; Debeaupuis, J.P.; Diaquin, M.; LopezMedrano, R.; Leal, F.; Latge, J.P. Cloning and disruption of the antigenic catalase gene of Aspergillus fumigatus. Infect. Immun., 1997, 65, 4718-724.

174. Gardiner, D.M/; Howlett, B.J. Bioinformatic and expression analysis of the putative gliotoxin biosynthetic gene cluster of Aspergillus fumigatus. FEMS Microbiol. Lett., 2005, 248, 241-48.

175. Shi, L.N.; Li, F.Q.; Huang, M.; Lu, J.F.; Kong, X.X.; Wang, S.Q.; Shao, H.F. Immunoproteomics based identification of thioredoxin reductase GliT and novel Aspergillus fumigatus antigens for serologic diagnosis of invasive aspergillosis. BMC Microbiol. 2012, 12,11.

176. Shen, D.K.; Noodeh, A.D.; Kazemi, A.; Grillot, R.; Robson, G.D.; Brugere, J.F. Characterisation and expression of phospholipases B from the opportunistic fungus Aspergillus fumigatus. FEMS Microbiol. Lett., 2004, 239, 87-93. 
177. Li, Y.; Zhang, L.; Wang, D.; Zhou, H.; Ouyang, H.; Ming, J.; Jin, C. Deletion of the MsdS/AfmsdC gene induces abnormal polarity and septation in Aspergillus fumigatus. Microbiology, 2008, 154, 1960-972.

178. Li, Y.; Fang, W.; Zhang, L.; Ouyang, H.; Zhou, H.; Luo, Y.; Jin, C. Class IIC alphamannosidase AfAms1 is required for morphogenesis and cellular function in Aspergillus fumigatus. Glycobiology, 2009, 19, 624-32.

179. Ebina, K.; Sakagami, H.; Yokota, K.; Kondo, H. Cloning and nucleotide sequence of cDNA encoding Asp-hemolysin from Aspergillus fumigatus. Biochim. Biophys. Acta, 1994, 1219, 148-50.

180. Wartenberg, D.; Lapp, K.; Jacobsen, I.D.; Dahse, H.M.; Kniemeyer, O.; Heinekamp, T.; Brakhage, A.A. Secretome analysis of Aspergillus fumigatus reveals Asp-hemolysin as a major secreted protein. Int. J. Med. Microbiol., 2011, 301, 602-11.

181. Yadav, P.K.; Singh, V.K.; Yadav, S.; Yadav, K.D.; Yadav, D. In silico analysis of pectin lyase and pectinase sequences. Biochemistry, 2009, 74, 1049-55.

182. Paris, S.; Wysong, D.; Debeaupuis, J.P.; Shibuya, K.; Philippe, B.; Diamond, R.D.; Latgé, J.P. Catalases of Aspergillus fumigatus. Infect. Immun., 2003, 71, 3551-62.

183. McDonagh, A.; Fedorova, N.D.; Crabtree, J.; Yu, Y.; Kim, S.; Chen, D.; Loss, O.; Cairns, T.; Goldman, G. Armstrong-James, D.; Haynes, K.; Haas, H.; Schrettl, M.; May, G.; Nierman, W.C.; Bignell, E. Sub-telomere directed gene expression during initiation of invasive aspergillosis. PLoS Pathog., 2008, 4, e1000154.

184. Reichard, U.; Cole, G.T.; Ruchel, R.; Monod, M. Molecular cloning and targeted deletion of PEP2 which encodes a novel aspartic proteinase from Aspergillus fumigatus. Int. J. Med. Microbiol., 2000, 290, 85-96. 
Table. List of newly identified potential immunoreactive molecules of $A$. fumigatus

\begin{tabular}{|c|c|c|c|c|c|c|c|c|c|c|}
\hline \multirow[t]{2}{*}{ S. No. } & \multirow[t]{2}{*}{ Uniprot ID } & \multirow{2}{*}{$\begin{array}{l}\text { Identification in } \\
\text { A. fumigatus }\end{array}$} & \multirow{2}{*}{$\begin{array}{l}\text { Biological } \\
\text { function }\end{array}$} & \multirow{2}{*}{$\begin{array}{l}\text { Immuno- } \\
\text { reactivity }\end{array}$} & \multicolumn{3}{|c|}{ Antigenicity } & \multirow[t]{2}{*}{ Characterized as } & \multirow[t]{2}{*}{ Reference } & \multirow[t]{2}{*}{ Potential use } \\
\hline & & & & & $\begin{array}{l}\text { Antige } \\
\text { Index }\end{array}$ & $\begin{array}{r}\text { iic B-Cell } \\
\text { Epitope }\end{array}$ & $\begin{array}{l}\text { T-cell } \\
\text { Epitope }\end{array}$ & & & \\
\hline 1 & P67875 & Asp f1-ribonuceoprotein & $\begin{array}{l}\text { Purine-specific } \\
\text { ribonuclease }\end{array}$ & IgG/IgE & High & Multiple & Several & Recombinant, Allergen & {$[83,84,129]$} & Diagnosis \\
\hline $2 \psi$ & P79017 & Asp f2-hypothetical protein & Not known & $\operatorname{IgG} / \mathrm{IgE}$ & High & Multiple & Several & $\begin{array}{l}\text { Recombinant, Allergen, } \\
\text { Drug target }\end{array}$ & $\begin{array}{l}{[85,86,125,} \\
129,132]\end{array}$ & $\begin{array}{l}\text { Diagnosis, } \\
\text { Therapy, } \\
\text { Drug development }\end{array}$ \\
\hline 3 & O60024 & Asp f4- hypothetical protein & Not known & $\mathrm{IgG} / \mathrm{IgE}$ & High & Multiple & Several & Recombinant, Allergen & {$[88,129]$} & $\begin{array}{l}\text { Diagnosis, } \\
\text { Therapy }\end{array}$ \\
\hline 4 & Q8J0P4 & $\begin{array}{l}\text { Asp f 9-probable glycosidase, } \\
\text { crfl }\end{array}$ & $\begin{array}{l}\text { Glycosidase, } \\
\text { Hydrolase }\end{array}$ & IgE & High & Multiple & Several & Recombinant, Allergen & {$[79,92,129]$} & Diagnosis \\
\hline 5 & O60022 & $\begin{array}{l}\text { Asp f 13/15-hypothetical } \\
\text { protein }\end{array}$ & Not known & $\operatorname{IgG} / \mathrm{IgE}$ & High & Multiple & Several & Recombinant, Allergen & $\begin{array}{l}{[129,160,} \\
161]\end{array}$ & $\begin{array}{l}\text { Diagnosis, } \\
\text { Therapy }\end{array}$ \\
\hline $6^{*}$ & Q4WEM3 & Hypothetical protein & Not known & $\mathrm{IgG} / \mathrm{IgE}$ & High & Multiple & Several & $\begin{array}{l}\text { Native, MS based, } \\
\text { Antigen }\end{array}$ & {$[129]$} & $\begin{array}{l}\text { Diagnosis, } \\
\text { Therapy }\end{array}$ \\
\hline $7^{*}$ & Q4WTF6 & $\begin{array}{l}\text { Aminotransferase-class V, } \\
\text { putative }\end{array}$ & $\begin{array}{l}\text { Amino } \\
\text { transferase }\end{array}$ & $\mathrm{IgG} / \mathrm{IgE}$ & High & Multiple & Several & $\begin{array}{l}\text { Native, MS based, } \\
\text { Antigen }\end{array}$ & [129] & $\begin{array}{l}\text { Diagnosis, } \\
\text { Therapy }\end{array}$ \\
\hline $8^{*}$ & P0C959 & $\begin{array}{l}\text { Dipeptidyl-peptidase-V } \\
\text { precursor, DppV }\end{array}$ & $\begin{array}{l}\text { Hydrolase, } \\
\text { Protease }\end{array}$ & $\mathrm{IgG} / \mathrm{IgE}$ & High & Multiple & Several & $\begin{array}{l}\text { Recombinant, Predicted } \\
\text { allergen }\end{array}$ & $\begin{array}{l}{[126,129,} \\
162]\end{array}$ & $\begin{array}{l}\text { Diagnosis, } \\
\text { Therapy }\end{array}$ \\
\hline 9* & Q9Y760 & Chitosanase & Chitinolysis & $\operatorname{IgG} / \mathrm{IgE}$ & High & Multiple & Several & $\begin{array}{l}\text { Recombinant, Enzyme, } \\
\text { Antigen. }\end{array}$ & $\begin{array}{l}{[126,129,} \\
163]\end{array}$ & $\begin{array}{l}\text { Diagnosis, } \\
\text { Therapy }\end{array}$ \\
\hline 10 & Q4WSV9 & $\begin{array}{l}\text { 1,3- } \beta \text {-glucanosyltransferase, } \\
\text { Bgt1 }\end{array}$ & $\begin{array}{l}\text { Glycosidase, } \\
\text { Hydrolase } \\
\text { Transferase }\end{array}$ & $\mathrm{IgG} / \mathrm{IgE}$ & High & Multiple & Several & $\begin{array}{l}\text { Native, Cell wall } \\
\text { molecule, Antigen }\end{array}$ & {$[129,164]$} & $\begin{array}{l}\text { Diagnosis, } \\
\text { Therapy }\end{array}$ \\
\hline 11 & Q4WXR8 & $\begin{array}{l}\text { Nuclear transport factor 2, } \\
\text { NTF-2 }\end{array}$ & $\begin{array}{l}\text { Transcription } \\
\text { factor }\end{array}$ & $\operatorname{IgG}$ & High & Multiple & Several & $\begin{array}{l}\text { Recombinant, Cross } \\
\text { reactive, predicted } \\
\text { allergen }\end{array}$ & {$[129,165]$} & Immuno-therapy \\
\hline 12 & Q4WW81 & Fucose specific lectin, FleA & Sugar binding & $\operatorname{IgG} / \mathrm{IgE}$ & High & Multiple & Several & $\begin{array}{l}\text { Recombinant, Cell wall } \\
\text { molecule, Antigen }\end{array}$ & {$[129,166]$} & $\begin{array}{l}\text { Diagnosis, } \\
\text { Therapy }\end{array}$ \\
\hline 13 & Q4WK08 & FG-GAP repeat protein & Ligand binding & $\mathrm{IgG} / \mathrm{IgE}$ & High & Multiple & Several & $\begin{array}{l}\text { Native, MS based, Cell } \\
\text { wall molecule, Antigen }\end{array}$ & {$[126,129]$} & $\begin{array}{l}\text { Diagnosis, } \\
\text { Therapy }\end{array}$ \\
\hline 14 & P41748 & Aspf10 aspergillopepsin-F & $\begin{array}{l}\text { Aspartyl } \\
\text { protease }\end{array}$ & IgE & High & Multiple & Several & Recombinant, Allergen & $\begin{array}{l}{[93,129,} \\
167]\end{array}$ & Diagnosis \\
\hline 15 & B0XT72 & $\begin{array}{l}\text { 1,3- } \beta \text {-glucanosyltransferase, } \\
\text { gel1 }\end{array}$ & $\begin{array}{l}\text { Transferase } \\
\text { activity }\end{array}$ & $\operatorname{IgG} / \operatorname{IgE}$ & High & Multiple & Several & $\begin{array}{l}\text { Native, Enzyme, Cell } \\
\text { wall molecule, Antigen }\end{array}$ & $\begin{array}{l}{[129,168,} \\
169,170]\end{array}$ & $\begin{array}{l}\text { Diagnosis, } \\
\text { Therapy }\end{array}$ \\
\hline $16^{*}$ & B0Y8H9 & $\begin{array}{l}\text { 1,3- } \beta \text {-glucanosyltransferase, } \\
\text { gel2 }\end{array}$ & $\begin{array}{l}\text { Transferase } \\
\text { activity }\end{array}$ & $\mathrm{IgG} / \mathrm{IgE}$ & High & Multiple & Several & $\begin{array}{l}\text { Native, Cell wall } \\
\text { molecule, Antigen }\end{array}$ & $\begin{array}{l}{[129,169,} \\
170]\end{array}$ & $\begin{array}{l}\text { Diagnosis, } \\
\text { Therapy }\end{array}$ \\
\hline 17 & A4D9F7 & Class V chitinase & $\begin{array}{l}\text { Glycosidase, } \\
\text { Hydrolase }\end{array}$ & $\operatorname{IgG} / \operatorname{IgE}$ & High & Multiple & Several & $\begin{array}{l}\text { Recombinant, Cell wall } \\
\text { degrading enzyme, } \\
\text { Antigen }\end{array}$ & $\begin{array}{l}{[126,129,} \\
171,172]\end{array}$ & $\begin{array}{l}\text { Diagnosis, } \\
\text { Therapy }\end{array}$ \\
\hline $18^{*}$ & Q92405 & Catalase-B, Cat-B & Heme binding & IgG/IgE & High & Multiple & Several & Recombinant, Antigen & $\begin{array}{l}{[125,126,} \\
129,173]\end{array}$ & $\begin{array}{l}\text { Diagnosis, } \\
\text { Therapy }\end{array}$ \\
\hline
\end{tabular}




\begin{tabular}{|c|c|c|c|c|c|c|c|c|c|c|}
\hline $19 \psi$ & E9RAH5 & Thioredoxin reductase, GliT & Reductase & IgE & High & Multiple & Several & $\begin{array}{l}\text { Recombinant, Toxin, } \\
\text { Antigen, Drug target }\end{array}$ & $\begin{array}{l}{[126,129,} \\
132,174, \\
175]\end{array}$ & $\begin{array}{l}\text { Diagnosis, } \\
\text { Drug development }\end{array}$ \\
\hline $20^{*}$ & B0XZV8 & Lysophospholipase-3, Plb3 & Lipolysis & $\operatorname{IgG} / \operatorname{IgE}$ & High & Multiple & Several & $\begin{array}{l}\text { Recombinant, Enzyme, } \\
\text { Antigen }\end{array}$ & $\begin{array}{l}{[129,170,} \\
176]\end{array}$ & $\begin{array}{l}\text { Diagnosis, } \\
\text { Therapy }\end{array}$ \\
\hline $21^{*}$ & B0Y 665 & Lysophospholipase-1, Plb1 & Lipolysis & $\mathrm{IgG} / \mathrm{IgE}$ & High & Multiple & Several & $\begin{array}{l}\text { Recombinant, Enzyme, } \\
\text { Antigen }\end{array}$ & $\begin{array}{l}{[117,129} \\
170,176]\end{array}$ & $\begin{array}{l}\text { Diagnosis, } \\
\text { Therapy }\end{array}$ \\
\hline $22^{*}$ & Q4WRZ5 & Mannosidase, MsdS & $\begin{array}{l}\text { Glycosidase, } \\
\text { Hydrolase }\end{array}$ & $\mathrm{IgG} / \mathrm{IgE}$ & High & Multiple & Several & $\begin{array}{l}\text { Recombinant, } \\
\text { Morphogenetic factor, } \\
\text { Antigen }\end{array}$ & $\begin{array}{l}{[126,129,} \\
177,178]\end{array}$ & $\begin{array}{l}\text { Diagnosis, } \\
\text { Therapy }\end{array}$ \\
\hline 23 & Q870C0 & Chitinase, Chi-B & Glycosidase & $\mathrm{IgG} / \mathrm{IgE}$ & High & Multiple & Several & $\begin{array}{l}\text { Recombinant, Enzyme, } \\
\text { Cell wall molecule, } \\
\text { Antigen }\end{array}$ & $\begin{array}{l}{[126,129} \\
171,172]\end{array}$ & $\begin{array}{l}\text { Diagnosis, } \\
\text { Therapy }\end{array}$ \\
\hline $24 \psi$ & O43099 & $\begin{array}{l}\text { IgE binding protein/Asp } \\
\text { f3/pmp20 }\end{array}$ & $\begin{array}{l}\text { Cell-redox, } \\
\text { homeostasis }\end{array}$ & $\mathrm{IgG} / \mathrm{IgE}$ & High & Multiple & Several & $\begin{array}{l}\text { Recombinant, Allergen, } \\
\text { Vaccine candidate, } \\
\text { Drug target }\end{array}$ & $\begin{array}{l}61,64,65, \\
87,127,128, \\
129,132] \\
\end{array}$ & $\begin{array}{l}\text { Diagnosis, } \\
\text { Therapy, } \\
\text { Drug development }\end{array}$ \\
\hline 25 & Q00050 & Asp-hemolysin, Asp-HS & $\begin{array}{l}\text { Cytolysis, } \\
\text { Hemolysis }\end{array}$ & $\operatorname{IgG}$ & High & Multiple & Several & $\begin{array}{l}\text { Recombinant, Invasion } \\
\text { enzyme, Antigen }\end{array}$ & $\begin{array}{l}{[129,179,} \\
180]\end{array}$ & $\begin{array}{ll}\text { Therapy } \\
\end{array}$ \\
\hline 26 & Q4WG16 & $\begin{array}{l}\text { GPI-anchored cell wall beta- } \\
1,3 \text {-endoglucanase EglC }\end{array}$ & $\begin{array}{l}\text { Glycosidase, } \\
\text { Hydrolase }\end{array}$ & $\mathrm{IgG} / \mathrm{IgE}$ & High & Multiple & Several & $\begin{array}{l}\text { Native, MS based, Cell } \\
\text { wall degrading enzyme, } \\
\text { Antigen }\end{array}$ & {$[126,129]$} & Diagnosis, Therapy \\
\hline 27 & Q4WFY5 & $\begin{array}{l}\text { Hypothetical protein } \\
\text { AFUA_3G00600 }\end{array}$ & Not known & $\mathrm{IgG} / \mathrm{IgE}$ & High & Multiple & Several & $\begin{array}{l}\text { Native, MS based, } \\
\text { Antigen }\end{array}$ & [129] & $\begin{array}{l}\text { Diagnosis, } \\
\text { Therapy }\end{array}$ \\
\hline 28 & B0Y2B3 & $\begin{array}{l}\text { Conserved hypothetical } \\
\text { protein }\end{array}$ & Not known & $\operatorname{IgG}$ & High & Multiple & Several & $\begin{array}{l}\text { Native, MS based, } \\
\text { Antigen }\end{array}$ & {$[129]$} & Immuno-therapy \\
\hline $29^{*}$ & Q4WIT0 & Pectate lyase $\mathrm{A}$ & Lyase & $\mathrm{IgG} / \mathrm{IgE}$ & High & Multiple & Several & $\begin{array}{l}\text { Native, In silico, MS } \\
\text { based, Antigen }\end{array}$ & {$[129,181]$} & $\begin{array}{l}\text { Diagnosis, } \\
\text { Therapy }\end{array}$ \\
\hline $30^{*} \psi$ & Q4WDJ0 & $\begin{array}{l}\text { NAD-dependent formate } \\
\text { dehydrogenase, AciA/Fdh }\end{array}$ & $\begin{array}{l}\text { Oxido- } \\
\text { reductase } \\
\text { activity }\end{array}$ & $\operatorname{IgE}$ & High & Multiple & Several & $\begin{array}{l}\text { Native MS based, } \\
\text { Antigen, Drug target }\end{array}$ & $\begin{array}{l}{[128,129,} \\
132]\end{array}$ & $\begin{array}{l}\text { Diagnosis, } \\
\text { Drug development }\end{array}$ \\
\hline $31^{*}$ & Q4WGP3 & $\begin{array}{l}\text { Malate dehydrogenase, NAD- } \\
\text { dependent }\end{array}$ & $\begin{array}{l}\text { Oxido- } \\
\text { reductase }\end{array}$ & IgE & High & Multiple & Several & $\begin{array}{l}\text { Native, MS based, } \\
\text { Predicted allergen }\end{array}$ & $\begin{array}{l}{[128,129,} \\
130]\end{array}$ & Diagnosis \\
\hline $32^{*}$ & Q7Z7W6 & $\begin{array}{l}\text { Bifunctional catalase- } \\
\text { peroxidase, Cat2 }\end{array}$ & $\begin{array}{l}\text { Catalase } \\
\text { Peroxidase }\end{array}$ & $\operatorname{IgE}$ & High & Multiple & Several & $\begin{array}{l}\text { Native, MS Based, } \\
\text { Antioxidant, Antigen }\end{array}$ & $\begin{array}{l}{[129,182,} \\
183]\end{array}$ & Diagnosis \\
\hline $33^{*}$ & Q4WJJ3 & Beta-glucosidase & $\begin{array}{l}\text { Glycosidase } \\
\text { Hydrolase }\end{array}$ & $\mathrm{IgG} / \mathrm{IgE}$ & High & Multiple & Several & $\begin{array}{l}\text { Native MS based, Cell } \\
\text { wall molecule, Antigen }\end{array}$ & [129] & $\begin{array}{l}\text { Diagnosis, } \\
\text { Therapy }\end{array}$ \\
\hline $34^{*}$ & Q4WD61 & $\begin{array}{l}\text { FAD/FMN-containing } \\
\text { isoamyl alcohol oxidase, } \\
\text { MreA }\end{array}$ & $\begin{array}{l}\text { FAD binding } \\
\text { Oxido- } \\
\text { reductase }\end{array}$ & $\mathrm{IgG} / \mathrm{IgE}$ & High & Multiple & Several & $\begin{array}{l}\text { Native MS based, Cell } \\
\text { wall molecule, Antigen }\end{array}$ & [129] & $\begin{array}{l}\text { Diagnosis, } \\
\text { Therapy }\end{array}$ \\
\hline $35^{*}$ & B0XS20 & $\begin{array}{l}\text { Glucose-6-phosphate } \\
\text { isomerase }\end{array}$ & Isomerase & $\operatorname{IgE}$ & High & Multiple & Several & $\begin{array}{l}\text { Native MS based, } \\
\text { Enzyme, Antigen }\end{array}$ & {$[129,130]$} & Diagnosis \\
\hline $36^{*} \psi$ & Q4WZX5 & $\begin{array}{l}\text { Sorbitol/xylulose reductase } \\
\text { Sou1-like }\end{array}$ & Oxidoreductase & $\operatorname{IgE}$ & High & Multiple & Several & $\begin{array}{l}\text { Native MS based, } \\
\text { Antigen, Drug target }\end{array}$ & {$[130]$} & $\begin{array}{l}\text { Diagnosis, } \\
\text { Drug development }\end{array}$ \\
\hline 37 & Q4WY02 & Proteasome component Prs2 & Hydrolase & IgE & High & Multiple & Several & $\begin{array}{l}\text { Native MS based, } \\
\text { Antigen }\end{array}$ & {$[130]$} & Diagnosis \\
\hline
\end{tabular}




\begin{tabular}{|c|c|c|c|c|c|c|c|c|c|c|}
\hline 38 & Q4WMR7 & Proteasome component Pre9 & Hydrolase & $\operatorname{IgE}$ & High & Multiple & Several & $\begin{array}{l}\text { Native MS based, } \\
\text { Antigen }\end{array}$ & [130] & Diagnosis \\
\hline $39 \psi$ & A4D9S0 & 6-phosphogluconolactonase & Hydrolase & $\operatorname{IgE}$ & High & Multiple & Several & $\begin{array}{l}\text { Native MS based, } \\
\text { Antigen, Drug target }\end{array}$ & {$[130,132]$} & $\begin{array}{l}\text { Diagnosis, } \\
\text { Drug development }\end{array}$ \\
\hline $40 \psi$ & Q4WUD7 & $\begin{array}{l}\text { Pyridoxine biosynthesis } \\
\text { protein }\end{array}$ & $\begin{array}{l}\text { Catalytic } \\
\text { activity }\end{array}$ & $\operatorname{IgE}$ & High & Multiple & Several & $\begin{array}{l}\text { Native MS based, } \\
\text { Antigen, Drug target }\end{array}$ & {$[130,132]$} & $\begin{array}{l}\text { Diagnosis, } \\
\text { Drug development }\end{array}$ \\
\hline $41 \psi$ & E9R3W5 & Spermidine synthase & Transferase & $\operatorname{IgE}$ & High & Multiple & Several & $\begin{array}{l}\text { Native MS based, } \\
\text { Antigen, Drug target }\end{array}$ & {$[130,132]$} & $\begin{array}{l}\text { Diagnosis, } \\
\text { Drug development }\end{array}$ \\
\hline 42 & Q4WWK6 & $\begin{array}{l}\text { Phosphoribosyl- } \\
\text { aminoimidazole- } \\
\text { succinocarboxamide synthase }\end{array}$ & Ligase & $\operatorname{IgE}$ & High & Multiple & Several & $\begin{array}{l}\text { Native MS based, } \\
\text { Antigen }\end{array}$ & {$[130]$} & Diagnosis \\
\hline 43 & Q4WX65 & Inorganic diphosphatase & Hydrolase & $\operatorname{IgE}$ & High & Multiple & Several & $\begin{array}{l}\text { Native MS based, } \\
\text { Antigen }\end{array}$ & {$[130]$} & Diagnosis \\
\hline 44 & Q4WJR3 & $60 \mathrm{~S}$ ribosomal protein $\mathrm{P} 0$ & $\begin{array}{l}\text { Ribosomal } \\
\text { ribonucleoprote } \\
\text { in, }\end{array}$ & $\operatorname{IgE}$ & High & Multiple & Several & $\begin{array}{l}\text { Native MS based, } \\
\text { Antigen }\end{array}$ & {$[130]$} & Diagnosis \\
\hline $45 \psi$ & Q4WTX0 & Adenosine kinase & $\begin{array}{l}\text { Kinase, } \\
\text { transferase }\end{array}$ & $\operatorname{IgE}$ & High & Multiple & Several & $\begin{array}{l}\text { Native MS based, } \\
\text { Antigen, Drug target }\end{array}$ & {$[130,132]$} & $\begin{array}{l}\text { Diagnosis, } \\
\text { Drug development }\end{array}$ \\
\hline $46 \psi$ & E9R9J7 & $\begin{array}{l}\text { Thiamine biosynthesis protein } \\
\text { (Nmt1) }\end{array}$ & $\begin{array}{l}\text { Function not } \\
\text { known }\end{array}$ & $\operatorname{IgE}$ & High & Multiple & Several & $\begin{array}{l}\text { Native MS based, } \\
\text { Antigen, Drug target }\end{array}$ & $\begin{array}{l}{[128,130,} \\
132]\end{array}$ & $\begin{array}{l}\text { Diagnosis, } \\
\text { Drug development }\end{array}$ \\
\hline $47 \psi$ & Q4WY39 & $\begin{array}{l}\text { Fructose-bisphosphate } \\
\text { aldolase, class II }\end{array}$ & Lyase & $\operatorname{IgE}$ & High & Multiple & Several & $\begin{array}{l}\text { Native MS based, } \\
\text { Antigen, Drug target }\end{array}$ & $\begin{array}{l}{[128,130,} \\
132]\end{array}$ & $\begin{array}{l}\text { Diagnosis, } \\
\text { Drug development }\end{array}$ \\
\hline $48 \psi$ & Q4WUP8 & Transaldolase & Transferase & $\operatorname{IgE}$ & High & Multiple & Several & $\begin{array}{l}\text { Native MS based, } \\
\text { Antigen, Drug target }\end{array}$ & $\begin{array}{l}{[128,130,} \\
132]\end{array}$ & $\begin{array}{l}\text { Diagnosis, } \\
\text { Drug development }\end{array}$ \\
\hline 49 & Q4WT41 & $\begin{array}{l}\text { S-adenosylmethionine } \\
\text { synthetase }\end{array}$ & Transferase, & $\operatorname{IgE}$ & High & Multiple & Several & $\begin{array}{l}\text { Native MS based, } \\
\text { Antigen }\end{array}$ & {$[130]$} & Diagnosis \\
\hline 50 & Q4WQK3 & Glutamine synthetase & Ligase & $\operatorname{IgE}$ & High & Multiple & Several & $\begin{array}{l}\text { Native MS based, } \\
\text { Antigen }\end{array}$ & {$[130]$} & Diagnosis \\
\hline $51 \psi$ & Q96X30 & Asp f22/ Enolase & Lyase & $\operatorname{IgE}$ & High & Multiple & Several & $\begin{array}{l}\text { Recombinant, Allergen, } \\
\text { Drug target }\end{array}$ & $\begin{array}{l}101,128, \\
130,132]\end{array}$ & $\begin{array}{l}\text { Diagnosis, } \\
\text { Drug development }\end{array}$ \\
\hline 52 & Q6A3P8 & Putative flavohaemoglobin & $\begin{array}{l}\text { Electron carrier, } \\
\text { Oxidoreductase }\end{array}$ & IgE & High & Multiple & Several & $\begin{array}{l}\text { Native MS based, } \\
\text { Antigen }\end{array}$ & {$[130]$} & Diagnosis \\
\hline $53 \psi$ & Q4WT69 & $\begin{array}{l}\text { Phosphoglycerate kinase } \\
\text { PgkA }\end{array}$ & Transferase & $\operatorname{IgE}$ & High & Multiple & Several & $\begin{array}{l}\text { Native MS based, } \\
\text { Antigen, Drug target }\end{array}$ & $\begin{array}{l}{[128,130,} \\
132]\end{array}$ & $\begin{array}{l}\text { Diagnosis, } \\
\text { Drug development }\end{array}$ \\
\hline $54 \psi$ & Q4WT91 & Adenosylhomocysteinase & Hydrolase & $\operatorname{IgE}$ & High & Multiple & Several & $\begin{array}{l}\text { Native MS based, } \\
\text { Antigen, Drug target }\end{array}$ & {$[130,132]$} & $\begin{array}{l}\text { Diagnosis, } \\
\text { Drug development }\end{array}$ \\
\hline 55 & Q4WQ64 & Phosphatidyl synthase & Hydrolase & $\operatorname{IgE}$ & High & Multiple & Several & $\begin{array}{l}\text { Native MS based, } \\
\text { Antigen }\end{array}$ & {$[130]$} & Diagnosis \\
\hline $56 \psi$ & Q4WM98 & $\begin{array}{l}\text { ATP citrate lyase subunit } \\
\text { (Acl), putatibe }\end{array}$ & Lyase, Ligase & $\operatorname{IgE}$ & High & Multiple & Several & $\begin{array}{l}\text { Native MS based, } \\
\text { Antigen, Drug target }\end{array}$ & {$[130,132]$} & $\begin{array}{l}\text { Diagnosis, } \\
\text { Drug development }\end{array}$ \\
\hline 57 & Q4WFT3 & $\begin{array}{l}\text { GMP synthase [glutamine- } \\
\text { hydrolyzing] }\end{array}$ & $\begin{array}{l}\text { Ligase, ATP } \\
\text { binding }\end{array}$ & $\operatorname{IgE}$ & High & Multiple & Several & $\begin{array}{l}\text { Native MS based, } \\
\text { Antigen }\end{array}$ & {$[130]$} & Diagnosis \\
\hline $58 \psi$ & Q4WN06 & $\begin{array}{l}\text { 6-phosphogluconate } \\
\text { dehydrogenase Gnd1 }\end{array}$ & $\begin{array}{l}\text { Oxidoreductase } \\
\text {, NADP } \\
\text { binding }\end{array}$ & $\operatorname{IgE}$ & High & Multiple & Several & $\begin{array}{l}\text { Native MS based, } \\
\text { Antigen, Drug target }\end{array}$ & $\begin{array}{l}{[128,130,} \\
132]\end{array}$ & $\begin{array}{l}\text { Diagnosis, } \\
\text { Drug development }\end{array}$ \\
\hline 59 & Q4X282 & $\begin{array}{l}\text { Gamma-glutamyl phosphate } \\
\text { reductase }\end{array}$ & $\begin{array}{l}\text { Oxidoreductase } \\
\text {, NADP } \\
\text { binding }\end{array}$ & $\operatorname{IgE}$ & High & Multiple & Several & $\begin{array}{l}\text { Native MS based, } \\
\text { Antigen }\end{array}$ & {$[130]$} & Diagnosis \\
\hline
\end{tabular}




\begin{tabular}{|c|c|c|c|c|c|c|c|c|c|c|}
\hline $60 \psi$ & Q4WWD5 & Glutamatecarboxy peptidase & $\begin{array}{l}\text { Carboxypeptida } \\
\text { se, metallo- } \\
\text { peptidase } \\
\text { protein } \\
\text { dimerizaion }\end{array}$ & $\operatorname{IgE}$ & High & Multiple & Several & $\begin{array}{l}\text { Native MS based, } \\
\text { Antigen, Drug target }\end{array}$ & {$[130,132]$} & $\begin{array}{l}\text { Diagnosis, } \\
\text { Drug development }\end{array}$ \\
\hline 61 & Q4X155 & $\begin{array}{l}\text { Secretory pathway gdp } \\
\text { dissociation inhibitor }\end{array}$ & $\begin{array}{l}\text { Rab-GDP } \\
\text { dissociation }\end{array}$ & $\operatorname{IgE}$ & High & Multiple & Several & $\begin{array}{l}\text { Native MS based, } \\
\text { Antigen }\end{array}$ & {$[130]$} & Diagnosis \\
\hline 62 & Q4WCS2 & Glucokinase GlkA & $\begin{array}{l}\text { Kinase, ATP } \\
\text { binding }\end{array}$ & $\operatorname{IgE}$ & High & Multiple & Several & $\begin{array}{l}\text { Native MS based, } \\
\text { Antigen }\end{array}$ & [130] & Diagnosis \\
\hline 63 & Q4X0J6 & $\begin{array}{l}\text { Bifunctional tryptophan } \\
\text { synthase TRPB }\end{array}$ & $\begin{array}{l}\text { Pyridoxal } \\
\text { phosphate } \\
\text { binding, }\end{array}$ & $\operatorname{IgE}$ & High & Multiple & Several & $\begin{array}{l}\text { Native MS based, } \\
\text { Antigen }\end{array}$ & [130] & Diagnosis \\
\hline 64 & Q4X144 & $\begin{array}{l}\text { 3-isopropylmalate } \\
\text { dehydratase }\end{array}$ & $\begin{array}{l}\text { Iron sulfur } \\
\text { cluster binding }\end{array}$ & IgE & High & Multiple & Several & $\begin{array}{l}\text { Native MS based, } \\
\text { Antigen }\end{array}$ & {$[130]$} & Diagnosis \\
\hline $65 \psi$ & Q4WRZ4 & $\begin{array}{l}\text { Phosphoribosyl-AMP } \\
\text { cyclohydrolase }\end{array}$ & $\begin{array}{l}\text { Dehydrogenase, } \\
\text { Hydrolase }\end{array}$ & $\operatorname{IgE}$ & High & Multiple & Several & $\begin{array}{l}\text { Native MS based, } \\
\text { Antigen, Drug target }\end{array}$ & {$[130,132]$} & $\begin{array}{l}\text { Diagnosis, } \\
\text { Drug development }\end{array}$ \\
\hline $66 \psi$ & Q4WUD3 & Aminopeptidase P & $\begin{array}{l}\text { Metallopeptidas } \\
\text { e, Hydrolase }\end{array}$ & IgE & High & Multiple & Several & $\begin{array}{l}\text { Native MS based, } \\
\text { Antigen, Drug target }\end{array}$ & {$[130,132]$} & $\begin{array}{l}\text { Diagnosis, } \\
\text { Drug development }\end{array}$ \\
\hline 67 & Q4X1H5 & $\begin{array}{l}\text { Mitochondrial Hsp70 } \\
\text { chaperone (Ssc70) }\end{array}$ & $\begin{array}{l}\text { ATP/unfolded } \\
\text { protein binding }\end{array}$ & $\operatorname{IgE}$ & High & Multiple & Several & $\begin{array}{l}\text { Native MS based, } \\
\text { Antigen }\end{array}$ & {$[128,130]$} & Diagnosis \\
\hline 68 & Q4WAM8 & Heat shock protein (Stil) & Stress response & IgE & High & Multiple & Several & $\begin{array}{l}\text { Native MS based, } \\
\text { Antigen }\end{array}$ & {$[130]$} & Diagnosis \\
\hline 69 & Q4WCM2 & Hsp70 chaperone (HscA) & ATP binding & IgE & High & Multiple & Several & $\begin{array}{l}\text { Native MS based, } \\
\text { Antigen }\end{array}$ & {$[130]$} & Diagnosis \\
\hline $70 \psi$ & E9RAB9 & Hsp70 chaperone Hsp88 & ATP binding & $\operatorname{IgE}$ & High & Multiple & Several & $\begin{array}{l}\text { Native MS based, } \\
\text { Antigen, Drug target }\end{array}$ & {$[130,132]$} & $\begin{array}{l}\text { Diagnosis, } \\
\text { Drug development }\end{array}$ \\
\hline $71 \psi$ & P40292 & $\begin{array}{l}\text { Asp f12/ Heat shock protein } \\
\mathrm{P} 90 / / \mathrm{Hsp} 90 / \mathrm{Hsp} 1\end{array}$ & $\begin{array}{l}\text { ATP/unfolded } \\
\text { protein binding }\end{array}$ & $\operatorname{IgE}$ & High & Multiple & Several & $\begin{array}{l}\text { Native MS based, } \\
\text { Antigen, Drug target }\end{array}$ & {$[130,132]$} & $\begin{array}{l}\text { Diagnosis, } \\
\text { Drug development }\end{array}$ \\
\hline 72 & Q4WJ30 & Molecular chaperone Hsp70 & ATP binding & $\operatorname{IgE}$ & High & Multiple & Several & $\begin{array}{l}\text { Native MS based, } \\
\text { Antigen }\end{array}$ & {$[130]$} & Diagnosis \\
\hline $73 \psi$ & Q4WV25 & ATP synthase $F 1, \beta$ subunit & $\begin{array}{l}\text { Hydrolase, } \\
\text { ATP/metal ion } \\
\text { binding }\end{array}$ & $\operatorname{IgE}$ & High & Multiple & Several & $\begin{array}{l}\text { Native MS based, } \\
\text { Antigen, Drug target }\end{array}$ & {$[130,132]$} & $\begin{array}{l}\text { Diagnosis, } \\
\text { Drug development }\end{array}$ \\
\hline $74 * \psi$ & Q4WJK8 & $40 \mathrm{~S}$ ribosomal protein $\mathrm{S} 3$ & $\begin{array}{l}\text { Ribonucleoprot } \\
\text { ein }\end{array}$ & $\operatorname{IgE}$ & High & Multiple & Several & $\begin{array}{l}\text { Native MS based, } \\
\text { Antigen, Drug target }\end{array}$ & {$[130,132]$} & $\begin{array}{l}\text { Diagnosis, } \\
\text { Drug development }\end{array}$ \\
\hline $75 \psi$ & Q4WLN1 & $\begin{array}{l}\text { Mitochondrial aconitate } \\
\text { hydratase }\end{array}$ & $\begin{array}{l}\text { Tricarboxlic } \\
\text { acid cycle } \\
\text { mediator }\end{array}$ & IgE & High & Multiple & Several & $\begin{array}{l}\text { Native MS based, } \\
\text { Antigen, Drug target }\end{array}$ & $\begin{array}{l}{[128,130,} \\
132]\end{array}$ & $\begin{array}{l}\text { Diagnosis, Drug } \\
\text { development }\end{array}$ \\
\hline $76 \psi$ & O42630 & Aspartic endopeptidase PEP2 & Protease & $\operatorname{IgE}$ & High & Multiple & Several & $\begin{array}{l}\text { Recombinant, Enzyme, } \\
\text { Vaccine candidate, } \\
\text { Antigen, Drug target }\end{array}$ & $\begin{array}{l}{[128,130,} \\
132,184]\end{array}$ & $\begin{array}{l}\text { Diagnosis, } \\
\text { Immuno-therapy, } \\
\text { Drug development }\end{array}$ \\
\hline $77 \psi$ & Q4WH99 & $\begin{array}{l}\text { Protein disulfide isomerase } \\
\text { Pdil }\end{array}$ & $\begin{array}{l}\text { Ca ion binding, } \\
\text { Isomerase }\end{array}$ & $\operatorname{IgG}$ & High & Multiple & Several & $\begin{array}{l}\text { Native MS based, } \\
\text { Antigen, Drug target }\end{array}$ & $\begin{array}{l}{[127,130,} \\
132]\end{array}$ & $\begin{array}{l}\text { Immuno-therapy, } \\
\text { Drug development }\end{array}$ \\
\hline $78 \psi$ & Q4X0G7 & $\begin{array}{l}\text { Translation elongation factor } \\
\text { EF-2 }\end{array}$ & GTPase, & $\operatorname{IgG}$ & High & Multiple & Several & $\begin{array}{l}\text { Native MS based, } \\
\text { Antigen, Drug target }\end{array}$ & {$[130,132]$} & $\begin{array}{l}\text { Immuno-therapy, } \\
\text { Drug development }\end{array}$ \\
\hline $79 \psi$ & Q4WNY2 & $\begin{array}{l}\text { Cobalamin-independent } \\
\text { methionine synthase MetH/D }\end{array}$ & $\begin{array}{l}\text { Methyltransfera } \\
\text { se Zn ion } \\
\text { binding }\end{array}$ & IgE & High & Multiple & Several & $\begin{array}{l}\text { Native MS based, } \\
\text { Antigen, Drug target }\end{array}$ & {$[130,132]$} & $\begin{array}{l}\text { Diagnosis, } \\
\text { Drug development }\end{array}$ \\
\hline
\end{tabular}




\begin{tabular}{|c|c|c|c|c|c|c|c|c|c|c|}
\hline $80 \psi$ & E9QYY1 & $\begin{array}{l}\text { Isocitrate dehydrogenase, } \\
\text { NAD-dependent }\end{array}$ & Oxidoreductase & $\operatorname{IgE}$ & High & Multiple & Several & $\begin{array}{l}\text { Native MS based, } \\
\text { Antigen, Drug target }\end{array}$ & {$[130,132]$} & $\begin{array}{l}\text { Diagnosis, } \\
\text { Drug development }\end{array}$ \\
\hline $81 \psi$ & Q4WP16 & $\begin{array}{l}\text { Phosphoribosylaminoimidazo } \\
\text { lecarboxamide } \\
\text { formyltransferase/IMP } \\
\text { cyclohydrolase }\end{array}$ & $\begin{array}{l}\text { Hydrolase, } \\
\text { Transferase }\end{array}$ & IgE & High & Multiple & Several & $\begin{array}{l}\text { Native MS based, } \\
\text { Antigen, Drug target }\end{array}$ & {$[130,132]$} & $\begin{array}{l}\text { Diagnosis, } \\
\text { Drug development }\end{array}$ \\
\hline 82 & Q4WTN7 & $\begin{array}{l}\text { Nucleosome assembly protein } \\
\text { Nap1 }\end{array}$ & $\begin{array}{l}\text { Nucleosome } \\
\text { assembly }\end{array}$ & $\operatorname{IgE}$ & High & Multiple & Several & $\begin{array}{l}\text { Native MS based, } \\
\text { Antigen }\end{array}$ & {$[130]$} & Diagnosis \\
\hline 83 & Q4WWZ8 & $\begin{array}{l}\text { Ran GTPase activating } \\
\text { protein } 1 \text { (RNA1 protein) }\end{array}$ & Protein binding & $\operatorname{IgE}$ & High & Multiple & Several & $\begin{array}{l}\text { Native MS based, } \\
\text { Antigen }\end{array}$ & {$[130]$} & Diagnosis \\
\hline 84 & Q4WZI4 & Curved DNA-binding protein & $\begin{array}{l}\text { DNA binding, } \\
\text { Hydrolase, } \\
\text { Aminopeptidas } \\
\mathrm{e}\end{array}$ & IgE & High & Multiple & Several & $\begin{array}{l}\text { Native MS based, } \\
\text { Antigen }\end{array}$ & [130] & Diagnosis \\
\hline 85 & Q4WXF1 & $\begin{array}{l}\text { Phosphoglycerate mutase, } \\
\text { 2,3-bisphosphoglycerate- } \\
\text { independent }\end{array}$ & $\begin{array}{l}\text { Isomerase, Mn } \\
\text { ion binding }\end{array}$ & $\operatorname{IgE}$ & High & Multiple & Several & $\begin{array}{l}\text { Native MS based, } \\
\text { Antigen, Drug target }\end{array}$ & {$[130,132]$} & $\begin{array}{l}\text { Diagnosis, } \\
\text { Drug development }\end{array}$ \\
\hline 86 & Q4WGP1 & $\begin{array}{l}\text { Pyruvate dehydrogenase } \\
\text { complex, dihydrolipoamide } \\
\text { acetyltransferase component }\end{array}$ & $\begin{array}{l}\text { Acetyl } \\
\text { transferase, } \\
\text { Protein binding }\end{array}$ & $\operatorname{IgE}$ & High & Multiple & Several & $\begin{array}{l}\text { Native MS based, } \\
\text { Antigen }\end{array}$ & {$[130]$} & Diagnosis \\
\hline $87^{*}$ & P20359 & ACT_BOTCI Actin & $\begin{array}{l}\text { ATP/protein } \\
\text { binding }\end{array}$ & $\operatorname{IgE}$ & High & Multiple & Several & $\begin{array}{l}\text { Native MS based, } \\
\text { Antigen }\end{array}$ & {$[130]$} & Diagnosis \\
\hline 88 & Q4WTK5 & $\begin{array}{l}\text { UPF0160 domain protein } \\
\text { MYG1 }\end{array}$ & $\begin{array}{l}\text { Function not } \\
\text { known }\end{array}$ & IgE & High & Multiple & Several & $\begin{array}{l}\text { Native MS based, } \\
\text { Antigen }\end{array}$ & {$[130]$} & Diagnosis \\
\hline 89 & Q4WPU2 & Homocitrate synthase & Acyltransferase & IgE & High & Multiple & Several & $\begin{array}{l}\text { Native MS based, } \\
\text { Antigen }\end{array}$ & [130] & Diagnosis \\
\hline 90 & Q4X099 & $\begin{array}{l}\text { Dihydroxy acid dehydratase } \\
\text { Ilv3 }\end{array}$ & Hydratase & IgE & High & Multiple & Several & $\begin{array}{l}\text { Native MS based, } \\
\text { Antigen }\end{array}$ & {$[130]$} & Diagnosis \\
\hline 91 & Q4WIQ6 & $\begin{array}{l}\text { Myo-inositol-phosphate } \\
\text { synthase }\end{array}$ & Isomerase & $\operatorname{IgE}$ & High & Multiple & Several & $\begin{array}{l}\text { Native MS based, } \\
\text { Antigen }\end{array}$ & {$[128,130]$} & Diagnosis \\
\hline $92 \psi$ & Q4WNQ8 & $\begin{array}{l}\text { Glutamate/Leucine/Phenylala } \\
\text { nine/Valine dehydrogenase }\end{array}$ & Oxidoreductse & IgE & High & Multiple & Several & $\begin{array}{l}\text { Native MS based, } \\
\text { Antigen, Drug target }\end{array}$ & $\begin{array}{l}{[128,130,} \\
132]\end{array}$ & $\begin{array}{l}\text { Diagnosis, } \\
\text { Drug development }\end{array}$ \\
\hline $93 \psi$ & Q4WMS1 & Assimilatory sulfite reductase & Oxidoreductase & $\operatorname{IgG}$ & High & Multiple & Several & $\begin{array}{l}\text { Native MS based, } \\
\text { Antigen, Drug target }\end{array}$ & {$[130,132]$} & $\begin{array}{l}\text { Immuno-therapy, } \\
\text { Drug development }\end{array}$ \\
\hline 94 & Q4WXF4 & $\begin{array}{l}\text { Serine } \\
\text { hydroxymethyltransferase }\end{array}$ & Transferase, & $\operatorname{IgE}$ & High & Multiple & Several & $\begin{array}{l}\text { Native MS based, } \\
\text { Antigen }\end{array}$ & {$[128,130]$} & Diagnosis \\
\hline 95 & Q4WTV5 & Alcohol dehydrogenase & $\begin{array}{l}\text { Oxidoreductase } \\
\text {, Zn ion binding }\end{array}$ & $\operatorname{IgE}$ & High & Multiple & Several & $\begin{array}{l}\text { Native MS based, } \\
\text { Antigen }\end{array}$ & {$[128,130]$} & Diagnosis \\
\hline 96 & Q4WE70 & $\begin{array}{l}\text { Glyceraldehyde 3-phosphate } \\
\text { dehydrogenase GpdA }\end{array}$ & $\begin{array}{l}\text { Oxidoreductase } \\
\text {, NAD binding }\end{array}$ & $\operatorname{IgE}$ & High & Multiple & Several & $\begin{array}{l}\text { Native MS based, } \\
\text { Antigen }\end{array}$ & {$[128,130]$} & Diagnosis \\
\hline $97 \psi$ & Q4WEU5 & Citrate synthase (Cit1) & Acyltransferase & $\operatorname{IgE}$ & High & Multiple & Several & $\begin{array}{l}\text { Native MS based, } \\
\text { Antigen, Drug target }\end{array}$ & {$[128,130]$} & $\begin{array}{l}\text { Diagnosis, } \\
\text { Drug development }\end{array}$ \\
\hline 98 & B0Y617 & $\begin{array}{l}\text { Zinc-containing alcohol } \\
\text { dehydrogenase, putative }\end{array}$ & $\begin{array}{l}\text { Oxidoreductase } \\
\text { Zn ion } \\
\text { binding }\end{array}$ & $\operatorname{IgE}$ & High & Multiple & Several & $\begin{array}{l}\text { Native MS based, } \\
\text { Antigen }\end{array}$ & {$[128,130]$} & Diagnosis \\
\hline
\end{tabular}

Proteins marked with an asterisk (*) have been updated in allergen database allergome.org as potential allergens of A.fumigatus.

Proteins marled with psi $(\psi)$ apart of their immuno-reactivity they were targeted by antifungal drugs in the proteome of $A$. fumigatus. 